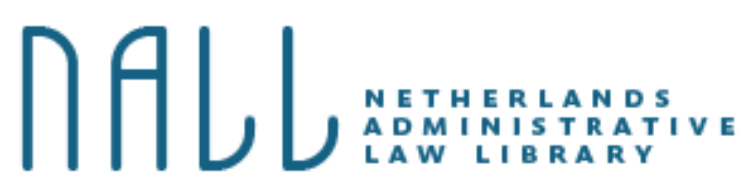

Citeerwijze van dit artikel:

Annemarie Drahmann, 'Transparantie en mededinging in het Nederlandse bestuursrecht: van opdrachten, via concessies naar vergunningen?', NALL 2012, oktober-december, DOI: 10.5553/NALL/.000007

DOI: 10.5553/NALL/.000007

\title{
Transparantie en mededinging in het Nederlandse bestuursrecht: van opdrachten, via concessies naar vergunningen?
}

\section{Annemarie Drahmann}

\section{Inleiding}

Het arrest van het Hof van Justitie van de Europese Unie inzake Betfair ${ }^{\mathbf{1}}$ heeft veel stof doen opwaaien. In het arrest oordeelt het Hof (kort samengevat) dat het Nederlandse gesloten vergunningstelsel van de Wet op de kansspelen (Wks) niet in overeenstemming is met artikel 49 EG-Verdrag (thans artikel 56 VWEU) inzake het vrij verkeer van diensten, in het bijzonder met het beginsel van gelijke behandeling en de daaruit voortvloeiende transparantieverplichting. De stilzwijgende verlenging van een Wks-vergunning aan bijvoorbeeld de Lotto zonder enige oproep tot mededinging is in strijd met het VWEU, aldus het Hof. Er zijn het afgelopen jaar vele publicaties over het arrest verschenen. ${ }^{2}$ Deze publicaties richten zich met name op de vraag onder welke voorwaarden het recht op vrij verkeer van diensten mag worden beperkt. In dit artikel wil ik mij richten op een andere vraag, namelijk wat dit arrest leert over de vraag op welke Nederlandse rechtsfiguren het 'Europese' transparantiebeginsel van toepassing zou kunnen zijn. In het arrest stelt het Hof over het vergunningstelsel van de Wks dat een Wks-vergunning dezelfde gevolgen heeft als de gevolgen van een 'concessieovereenkomst voor diensten', namelijk dat andere ondernemingen die mogelijk geïnteresseerd zouden zijn in het verrichten van de activiteit, niet meer voor vergunning- of concessieverlening in aanmerking komen. De transparantieverplichting moet blijkens het arrest (ook) worden nagekomen als een lidstaat aan één ondernemer het 'exclusieve recht' wil verlenen om een economische activiteit te verrichten, ongeacht de wijze van selectie van deze ondernemer. Om de reikwijdte van het transparantiebeginsel te kunnen bepalen is van belang te bezien door middel van welke rechtsfiguren een dergelijk exclusief recht kan worden verleend. Blijkens het arrest is dit niet alleen het geval bij 'concessieovereenkomsten', maar ook bij 'vergunningen'. Deze rechtsfiguren hebben in het Europees recht en het Nederlands (bestuurs)recht een eigen betekenis. Als de betekenis van dezelfde rechtsfiguren afhankelijk van 
de Europese of nationale context zou verschillen, kan dit tot begripsverwarring leiden. In dit artikel zal ik een aantal mogelijke knelpunten en oplossingen beschrijven.

Eerst zal ik een korte achtergrondschets geven van het Betfair-arrest (paragraaf 2). In paragraaf 3 wordt daarna ingegaan op de rechtsfiguur 'concessie' en het verlenen van 'exclusieve rechten'. Meer in het bijzonder zal ik achtereenvolgens ingaan op de 'opdracht' (3.2) en de 'concessie' (3.3). Daarna komen de verschillen tussen een opdracht en een concessie aan de orde (3.4). Vervolgens zal worden ingegaan op de begrippen 'exclusief recht' en 'uitsluitend recht' (3.5). In paragraaf 4 wordt ingegaan op de rechtsfiguur 'vergunning' en op de vraag of een vergunning onder omstandigheden als een concessie in de zin van de aanbestedingsrichtlijnen kan worden aangemerkt. Door deze analyse kan worden bezien wat het Hof van Justitie in het Betfair-arrest bedoelt met een 'concessieovereenkomst' en 'vergunningstelsel'. De vervolgstap is dan om de conclusies van deze Europeesrechtelijke analyse te vertalen naar de Nederlandse rechtspraktijk. Hiertoe zal ik in paragraaf 5 ingaan op de vraag of de Aanwijzingen voor de regelgeving (Ar) gewijzigd zouden moeten worden. In paragraaf 6 zullen ter illustratie een paar concrete Nederlandse vergunningstelsels worden beschreven waarmee een exclusief recht als bedoeld in het Betfair-arrest lijkt te worden verleend. Paragraaf 7 bevat een afronding.

\section{Het Betfair-arrest in het kort}

De Wks bepaalt dat aan één rechtspersoon vergunning kan worden verleend voor het organiseren van sportprijsvragen. Daarnaast kan er één vergunning worden verleend voor het organiseren van een totalisator. ${ }^{\mathbf{3}} \mathrm{Er}$ is dus sprake van een gesloten vergunningstelsel. Er wordt slechts één vergunning afgegeven per toegestaan kansspel. De Stichting de Nationale Sporttotalisator, beter bekend als De Lotto, is sinds 1961 (!) vergunninghoudster voor de organisatie van sportprijsvragen, de lotto en het cijferspel. De vergunning voor het organiseren van een totalisator is verleend aan Scientific Games Racing BV (SGR). Sporting Exchange Ltd, h.o.d.n. 'Betfair' is gevestigd in het Verenigd Koninkrijk en biedt via internet en telefoon weddenschappen over sportevenementen en paardenrennen aan. Betfair wil haar diensten ook actief op de Nederlandse markt aanbieden en dient daarom twee vergunningaanvragen in. Deze aanvragen worden door de Minister van Justitie afgewezen met een verwijzing naar het gesloten vergunningstelsel van de Wks. Betfair heeft ook bezwaar gemaakt tegen de verlenging van de vergunningen aan De Lotto en SGR. De rechtbank Den Haag heeft op 8 december 2006 dit beroep van Betfair (grotendeels) ongegrond verklaard. ${ }^{4}$ In hoger beroep stelt de Afdeling bestuursrechtspraak van de Raad van State op 14 mei 2008 prejudiciële vragen aan het Hof van Justitie. ${ }^{\mathbf{5}}$ De eerste vraag is of het gesloten stelsel van de Wks in strijd is met artikel 49 EG-Verdrag. Het Hof oordeelde eerder dat beperking van het vrij verkeer van diensten, zoals neergelegd in artikel 49 EG-Verdrag, is toegestaan indien deze beperking kan worden gerechtvaardigd door dwingende redenen van algemeen belang. De doelstellingen om consumentenbescherming te waarborgen en om criminaliteit en gokverslaving te bestrijden, waarop het gesloten stelsel van de Wks is gefundeerd, kunnen volgens het Hof worden aangemerkt als dwingende redenen van algemeen belang. In beginsel is het éénvergunningstelsel van de Wks dus gerechtvaardigd. De vervolgvraag is dan of 
de verlenging van de Wks-vergunning, zonder oproep tot mededinging, een geschikt en evenredig middel vormt ter verwezenlijking van de hiervoor genoemde op dwingende redenen van algemeen belang gefundeerde doelstellingen. Daarbij is van belang dat onduidelijk was of de rechtspraak die het Hof had ontwikkeld op het gebied van dienstenconcessies op het gebied van de kansspelen, ook van toepassing was op vergunningverlening. In deze eerdere rechtspraak heeft het Hof geoordeeld dat, hoewel concessieovereenkomsten voor diensten niet vallen binnen de werkingssfeer van de aanbestedingsrichtlijnen, de overheden die concessieovereenkomsten sluiten wel "de fundamentele regels van het EG-Verdrag in het algemeen, met name artikel $49 \mathrm{EG}$, en in het bijzonder het beginsel van gelijke behandeling en het verbod van discriminatie op grond van nationaliteit alsmede de daaruit voortvloeiende transparantieverplichting”, in acht moeten nemen. Volgens vaste jurisprudentie van het Hof van Justitie, houdt deze transparantieverplichting in dat de concessieverlenende instantie aan elke potentiële inschrijver een passende mate van openbaarheid moet garanderen, zodat de openbaredienstenconcessie voor mededinging openstaat en de gunningsprocedures op onpartijdigheid kunnen worden getoetst, zonder noodzakelijkerwijs te impliceren dat een aanbesteding moet worden uitgeschreven. ${ }^{6}$

De Afdeling vroeg zich af of deze jurisprudentie over concessieovereenkomsten ook van toepassing zou zijn op het gesloten vergunningstelsel van de Wks. Het Hof oordeelt in antwoord op de prejudiciële vragen dat dit inderdaad het geval is: "Dat de afgifte van één vergunning niet gelijkstaat aan een concessieovereenkomst voor diensten, kan er op zich geen rechtvaardiging voor vormen dat bij de verlening van een administratieve vergunning zoals aan de orde in het hoofdgeding, de uit artikel 49 EG voortvloeiende vereisten, met name het beginsel van gelijke behandeling en de transparantieverplichting, niet in acht worden genomen."7 De transparantieverplichting is "immers een dwingende prealabele voorwaarde van het recht van een lidstaat om aan één ondernemer het exclusieve recht te verlenen om een economische activiteit te verrichten, ongeacht de wijze van selectie van deze ondernemer. Een dergelijke verplichting dient ook toepassing te vinden in een systeem waarin de autoriteiten van een lidstaat in het kader van de uitoefening van hun overheidsbevoegdheden aan één enkele ondernemer vergunning verlenen, aangezien de gevolgen van een dergelijke vergunning jegens in andere lidstaten gevestigde ondernemingen, die mogelijk geïnteresseerd zouden zijn in het verrichten van deze activiteit, dezelfde zijn als die van een concessieovereenkomst voor diensten. [curs. AD]"8 Het Hof overweegt verder dat Nederland mag kiezen voor een éénvergunningstelsel, maar dat dit stelsel geen rechtvaardiging kan vormen voor een werkwijze waardoor het Europese beginsel van het vrij verrichten van diensten van zijn nuttige werking wordt beroofd. Wil een stelsel van voorafgaande administratieve vergunning in zo'n geval gerechtvaardigd zijn dan moet het zijn gebaseerd op objectieve criteria, die niet-discriminerend en vooraf kenbaar zijn. Het beginsel van gelijke behandeling en de transparantieverplichting brengen vervolgens met zich dat aan deze objectieve criteria voldoende bekendheid moet worden gegeven.9 ${ }^{9}$ De Wksvergunningen aan De Lotto en SGR zijn, zonder enige oproep tot mededinging, verlengd met respectievelijk drie en vijf jaar. Deze niet-transparante verlengingsprocedure heeft belet dat andere exploitanten hun interesse in de uitoefening van de te vergunnen activiteit kenbaar konden maken. Het Hof 
oordeelt verder dat de gevolgen van het toelaten van mededinging op de markt van de kansspelen moet worden onderscheiden van de gevolgen van het toelaten van mededinging voor de toekenning van de betrokken opdracht. Ten slotte overweegt het Hof dat als de vergunning zou worden verleend aan 'een openbare exploitant wiens beheer onder rechtstreeks toezicht staat van de Staat of een particuliere exploitant op wiens activiteiten de overheid een strenge controle kan uitoefenen' de toekenning of de verlenging van exclusieve rechten voor de exploitatie van kansspelen ten gunste van één exploitant, zonder oproep tot mededinging, niet onevenredig is. ${ }^{\mathbf{1 0}}$ Het Hof vergelijkt in het arrest (de effecten van) een éénvergunningstelsel met een concessiestelsel, omdat bij beide een exclusief recht wordt verleend.

De Afdeling is op grond van dit arrest vervolgens nagegaan of De Lotto en SGR kunnen worden aangemerkt als een particuliere exploitant op wiens activiteiten de overheid een strenge controle kan uitoefenen. Op 23 maart 2011 oordeelt de Afdeling dat dit niet het geval is. ${ }^{\mathbf{1 1}}$ Voor een uitgebreide analyse van de vraag wanneer sprake is van een dwingende reden van algemeen belang en wanneer voldaan kan worden aan het door het Hof van Justitie geformuleerde toezichtcriterium, verwijs ik graag naar de artikelen van Stergiou ${ }^{\mathbf{1 2}}$, Mulder ${ }^{\mathbf{1 3}}$, Adriaanse, Barkhuysen en Van den Bogaert ${ }^{\mathbf{1 4}}$ en Van der Beek $\mathbf{B}^{\mathbf{1 5}}$.

Dat het arrest van het Hof geen eendagsvlieg of uitglijder is, blijkt uit het kort daarop gewezen Engelmann-arrest, ${ }^{\mathbf{1 6}}$ waarin de overwegingen van het Hof uit het Betfair-arrest over de toepassing van het transparantiebeginsel bij vergunningverlening worden herhaald.

Wolswinkel stelt terecht in zijn annotatie bij het Betfair-arrest ${ }^{\mathbf{1 7}}$ dat als wordt uitgegaan van een strikte scheiding tussen privaatrecht (concessieovereenkomsten) en publiekrecht (schaarse vergunningen), het arrest van het Hof revolutionair mag lijken, maar dat de uitspraak bezien vanuit het Europese perspectief van de interne markt en de fundamentele vrijheden geen verrassing kan worden genoemd. Het Hof kijkt in zijn jurisprudentie namelijk niet naar de vorm van de gekozen rechtsfiguur (zoals publiek- of privaatrecht), maar naar het effect van de overheidsmaatregel. Als het gevolg van een overheidsstelsel is dat het vrij verkeer van diensten beperkt wordt, ongeacht of dit een vergunning, een (concessie)overeenkomst of nog een andere rechtsfiguur is, dan moeten de vereisten van artikel 56 VWEU en de daaruit voortvloeiende transparantieverplichting in acht worden genomen. ${ }^{\mathbf{1 8}}$ In de Nederlandse literatuur wordt echter de vorm (een privaatrechtelijke concessieovereenkomst of een publiekrechtelijke vergunning) vaak als het essentiële criterium genoemd om te bepalen of een dienst moet worden aanbesteed of niet. ${ }^{\mathbf{1 9}}$ Gelet op de materiële benadering van het Hof is die formele benadering niet toereikend, maar moet worden bezien welke nationale rechtsfiguren voldoen aan het materiële criterium van het Hof.

Ik zal daarom in de volgende paragraaf ingaan op verschillende rechtsfiguren waarbij het transparantiebeginsel van toepassing zou kunnen zijn: de 'vergunning', de 'opdracht' en de 'concessie'. Daarbij zal ook worden ingegaan op de (overige) verschillen tussen deze rechtsfiguren naar Europees recht.

\section{De concessie en de verlening van exclusieve rechten}

\subsection{Inleiding}


Het Hof van Justitie stelt in het Betfair-arrest dat het gesloten vergunningstelsel van de Wks verschilt van een concessieovereenkomst, maar dezelfde gevolgen heeft. Het Hof beoordeelt de vraag of sprake is van een 'opdracht' of 'concessie' uitsluitend op basis van het Unierecht. ${ }^{\mathbf{2 0}}$ Daarom zal ik nu achtereenvolgens ingaan op de 'opdracht' (3.2) en de 'concessie' (3.3). Daarna komen de verschillen tussen een opdracht en een concessie aan de orde (3.4). Vervolgens zal worden ingegaan op de begrippen 'exclusief recht' en 'uitsluitend recht' (3.5). Gelet op het feit dat het Betfair-arrest betrekking heeft op het verrichten van een dienst (kansspelaanbod) en niet op een werk of levering, wordt hierna met name ingegaan op concessieovereenkomsten voor diensten. Ook merk ik voor de vraag naar de mogelijke gevolgen van het Betfair-arrest hier op dat het VWEU alleen van toepassing is bij grensoverschrijdendheid. De verdragsbepalingen inzake het vrij verkeer van diensten zijn niet van toepassing bij zuiver interne situaties. ${ }^{\mathbf{2 1}}$ De vraag wanneer sprake is van een zuiver interne situatie mag echter niet te terughoudend worden beantwoord. ${ }^{\mathbf{2 2}}$ In dit artikel wordt een aantal nationale vergunningstelsels in algemene zin beschreven. Daarbij wordt er dus vanuit gegaan dat er in beginsel sprake is van een grensoverschrijdend element en het VWEU dus van toepassing is. Verder kan met reden de vraag worden gesteld of het wenselijk is dat bij grensoverschrijdende situaties andere normen (zoals een transparantiebeginsel) zouden gelden dan bij zuiver interne situaties.

Beantwoording van die vraag gaat het bestek van deze bijdrage te buiten. Wel kan ook dit aanknopingspunt zijn om het transparantiebeginsel van belang te achten zonder dat het Unierecht van toepassing is.

\subsection{De opdracht}

Aanbestedingsrichtlijn 2004/18/EG is primair van toepassing op (bepaalde) overheidsopdrachten. In essentie heeft een overheidsopdracht betrekking op inkoopactiviteiten van de overheid. In Richtlijn 2004/18/EG worden 'overheidsopdrachten' gedefinieerd als schriftelijke overeenkomsten onder bezwarende titel die tussen een of meer ondernemers en een of meer aanbestedende diensten zijn gesloten en betrekking hebben op de uitvoering van werken, de levering van producten of de verlening van diensten. ${ }^{\mathbf{2 3}}$ De definitie van 'overheidsopdracht' bevat twee belangrijke elementen, namelijk 'overeenkomst' en 'onder bezwarende titel'. Op deze twee elementen wordt hierna in paragraaf 4.2 ingegaan.

Op grond van artikel 2 van Richtlijn 2004/18/EG moeten aanbestedende diensten transparant handelen. Buiten twijfel staat dan ook dat het transparantiebeginsel op opdrachtverlening van toepassing is. Daarom zal de opdracht in dit artikel verder niet aan de orde komen. ${ }^{\mathbf{2 4}}$

\subsection{De concessie}

Volgens vaste jurisprudentie van het Hof van Justitie is het transparantiebeginsel ook van toepassing op concessieverlening. ${ }^{25}$ Omdat het Europese aanbestedingsrecht een eigen omschrijving van het concessiebegrip heeft, zal ik deze hieronder toelichten.

Een concessie vertoont grote gelijkenissen met een opdracht. De definitie van een concessieovereenkomst voor diensten in Richtlijn 2004/18/EG bepaalt immers zelf al dat het een overeenkomst is "met dezelfde kenmerken als een 
overheidsopdracht voor diensten met uitzondering van het feit dat de tegenprestatie voor de te verlenen diensten bestaat hetzij uit uitsluitend het recht de dienst te exploiteren, hetzij uit dit recht, gepaard gaande met een prijs." ${ }^{26}$ Het essentiële verschil tussen een opdracht en een concessie is dus gelegen in de tegenprestatie: de tegenprestatie bestaat bij een concessie uit het verlenen van een recht. Een concreet voorbeeld van een concessie is de concessieverlening op grond van de Wet personenvervoer 2000 (Wp2000). Bij besluit wordt een concessie verleend voor het exclusieve recht om openbaar vervoer te verrichten. In paragraaf 6.2 wordt nader ingegaan op deze concessieverlening. Hieruit zal blijken dat de concessiehouder op grond van de Wp20oo niet alleen het (exclusieve) recht, maar ook de plicht heeft het openbaar vervoer te verrichten.

Op dit moment bestaan er twee Europese aanbestedingsrichtlijnen ${ }^{\mathbf{2 7}}$ en is er geen concessierichtlijn. Op 20 december 2011 heeft de Europese Commissie echter een voorstel voor nieuwe aanbestedingsrichtlijnen gepubliceerd alsmede een voorstel voor een richtlijn betreffende de gunning van concessieopdrachten. ${ }^{\mathbf{2 8}}$ In dit laatste voorstel wordt een concessie voor diensten gedefinieerd als 'een contract onder bezwarende titel dat schriftelijk tussen een of meer ondernemers en een of meer aanbestedende diensten of aanbestedende entiteiten wordt gesloten en de verrichting van diensten (...) als voorwerp heeft, waarbij de tegenprestatie voor de te verrichten diensten bestaat hetzij uitsluitend in het recht de diensten die het voorwerp van het contract vormen, te exploiteren, hetzij in dit recht, gepaard gaande met een prijs. ${ }^{\mathbf{2 9}}$

Onderdeel van de begripsomschrijving van een concessie is de uitvoeringsplicht. Op het belang van de uitvoeringsplicht wordt in paragraaf 4.2 ingegaan. De vraag kan namelijk worden gesteld of een vergunning met een uitvoeringsplicht eigenlijk niet gekwalificeerd zou kunnen worden als een concessie.

Als in het vervolg van dit artikel wordt gesproken over de 'concessie' of 'opdracht' dan gaat het uitdrukkelijk om de uitleg van de begrippen zoals deze voortvloeien uit het Unierecht. Dit is van belang nu er ook andere meer nationaal georiënteerde beschrijvingen van het concessiebegrip worden gehanteerd. Deze worden in paragraaf 5 kort genoemd. Indien in dit artikel wordt gesproken over een 'concessie' wordt niet gedoeld op deze Nederlandse, historische betekenis(sen) van de 'concessie', maar op de huidige Unierechtelijke betekenis, zijnde: een schriftelijke overeenkomst onder bezwarende titel die tussen een of meer ondernemers en een of meer aanbestedende diensten is gesloten en betrekking heeft op de verlening van diensten, waarbij de tegenprestatie voor de te verlenen diensten bestaat hetzij uit uitsluitend het recht de dienst te exploiteren, hetzij uit dit recht, gepaard gaande met een prijs.

\subsection{Verschillen tussen de opdracht en concessie}

Zoals gesteld is het eerste en essentiële verschil tussen een opdracht en een concessie gelegen in de tegenprestatie: de rechtstreekse betaling voor een dienst respectievelijk het verlenen van een (exploitatie)recht voor die dienst.

Dit is echter niet het enige verschil. Een tweede verschil is dat bij concessieverlening ook sprake moet zijn van de overdracht van het exploitatierisico. Dit wordt expliciet bepaald in het voorstel voor een concessierichtlijn. Gesteld wordt dat het recht om de diensten te exploiteren, de 
overdracht van het wezenlijk operationeel risico aan de concessiehouder inhoudt. ${ }^{30}$

Dat er (nog) geen concessierichtlijn is, betekent niet dat de Europese Commissie tot op heden geen uitleg heeft gegeven aan het begrip concessie. $\mathrm{Al}$ in 2000 (dus voor de inwerkingtreding van de huidige aanbestedingsrichtlijnen) heeft de Europese Commissie een Interpretatieve mededeling over concessieovereenkomsten in het communautaire recht gepubliceerd waarin wordt gesteld dat de overdracht van de verantwoordelijkheid voor de exploitatie kenmerkend is voor concessieovereenkomsten voor dienstverlening. ${ }^{\mathbf{3 1}}$ Dat het cruciale verschil tussen een concessie en opdracht is gelegen in de tegenprestatie en risico-overdracht blijkt verder uit vaste jurisprudentie van het Hof van Justitie, zoals het arrest Stadler/Passau..$^{\mathbf{2}}$ Het Hof oordeelt dat uit de vergelijking van de definities van overheidsopdracht voor diensten en concessieovereenkomst voor diensten volgt dat het verschil tussen een overheidsopdracht voor diensten en een concessieovereenkomst voor diensten is gelegen in de tegenprestatie voor de dienstverlening. De opdracht voor diensten behelst een tegenprestatie die, ook al is dit niet de enige tegenprestatie, door de aanbestedende dienst rechtstreeks aan de dienstverrichter wordt betaald. Bij een concessieovereenkomst voor diensten bestaat de tegenprestatie voor de dienstverlening in het recht om de dienst te exploiteren, al dan niet gepaard gaande met een prijs. Voorts volgt uit de jurisprudentie dat de concessieovereenkomst voor diensten impliceert dat de opdrachtnemer het aan de exploitatie van de betrokken diensten verbonden risico draagt, en dat de omstandigheid dat het aan de verlening van de dienst verbonden risico niet wordt overgedragen op de dienstverrichter, erop duidt dat de bedoelde transactie een overheidsopdracht voor diensten vormt en niet een concessieovereenkomst voor diensten. 33

In de memorie van toelichting bij de Aanbestedingswet 2012 (die het Besluit aanbestedingsregels voor overheidsopdrachten (Bao) zal vervangen) wordt eveneens benadrukt dat het verschil tussen een concessie en overheidsopdracht is gelegen in de tegenprestatie en dat van belang is dat het exploitatierisico bij de concessiehouder wordt gelegd. $\mathbf{3 4}$

Een derde verschil tussen een opdracht en een concessie zou kunnen zijn gelegen in het soort activiteiten waarvoor een dienstenconcessie de geschikte rechtsvorm is. Concessies worden namelijk (meestal) verleend voor diensten die in het algemeen belang zijn. In de Interpretatieve Mededeling wordt gesteld dat concessieovereenkomsten voor dienstverlening normaliter activiteiten betreffen die, gezien hun aard en object en de regels waaraan zij zijn gebonden, onder de verantwoordelijkheid van de staat kunnen vallen en die het object kunnen zijn van exclusieve of bijzondere rechten. ${ }^{35}$ Op deze exclusieve of bijzondere rechten wordt in de volgende paragraaf ingegaan (paragraaf 3.5). Nijhof stelt dat een concessie geschikt is bij bepaalde economische premissen. Een concessie is volgens haar een bestuursinstrument van de overheid dat in het algemeen wordt gebruikt om tegemoet te komen aan marktfalen in de vorm van een natuurlijk monopolie. Dit is bijvoorbeeld het geval bij drinkwaterlevering voor de aanleg van een leidingnetwerk. Concurrentie om de markt is wel mogelijk, maar concurrentie op de markt niet. Door middel van het verlenen van een recht kan worden gegarandeerd dat zowel in de rendabele als onrendabele sectoren geleverd wordt tegen maatschappelijk wenselijke voorwaarden. ${ }^{\mathbf{3 6}} \mathrm{Nu}$ dit derde 
element geen onderdeel vormt van de definitie van een concessie in Richtlijn 2004/18/EG is dit echter geen juridisch relevant verschil, maar kan het wel een rol spelen bij de beleidsmatige keuze voor een concessiesysteem.

Samenvattend kan worden gesteld dat het eerste verschil tussen een opdracht en concessie ligt in de tegenprestatie: bij een concessie wordt een (exploitatie)recht verleend, terwijl bij een opdracht (rechtstreeks) wordt betaald voor een dienst. Een tweede verschil is dat bij een concessie sprake moet zijn van de overdracht van het exploitatierisico naar de concessiehouder. Een derde verschil dat soms wordt genoemd is dat concessies worden verleend voor diensten die in het algemeen belang zijn. Door middel van de concessieverlening kan worden gegarandeerd dat de dienst wordt verleend tegen maatschappelijk wenselijke voorwaarden.

\section{Exclusief recht: een uitsluitend recht?}

Het Betfair-arrest heeft betrekking op de verlening van een 'exclusief recht' bij administratieve vergunning. Het begrip 'exclusief recht' komt niet voor in de Nederlandse vertaling van het VWEU en slechts eenmaal in de titel van artikel 3 van de aanbestedingsrichtlijnen. ${ }^{37}$ Het begrip 'bijzondere of uitsluitende rechten' komt wel voor in zowel het VWEU ${ }^{38}$ als de aanbestedingsrichtlijnen ${ }^{39}$. Niet uitgesloten is dat de begrippen 'exclusief' en 'uitsluitend' als synoniemen van elkaar beschouwd moeten worden. Aanknopingspunt hiervoor is ook dat in de Engelse versie van zowel het Betfair-arrest als Richtlijn 2004/18/EG wordt gesproken over het verlenen van 'exclusive rights'.

Als het woord 'exclusief recht' in het Betfair-arrest dezelfde betekenis heeft als het begrip 'uitsluitend recht' in het VWEU en de aanbestedingsrichtlijnen zou het transparantiebeginsel van toepassing zijn op besluiten waarbij een 'uitsluitend recht' (of exclusief recht) of 'bijzonder recht' wordt verleend. Daarom wordt hierna ingegaan op de begrippen 'uitsluitend recht' en 'bijzonder recht'. Hierbij zal ingegaan worden op (i) de definitie van de begrippen, (ii) de verhouding tussen het primaire Unierecht en de aanbestedingsrichtlijnen en (iii) de vraag hoe een exclusief recht gevestigd kan worden.

De (huidige) aanbestedingsrichtlijnen bevatten niet een duidelijke definitie van de begrippen 'uitsluitend recht' en 'bijzonder recht'. 40 $^{\mathbf{0}}$ Het Bao, dat een implementatie is van de aanbestedingsrichtlijnen, bevat wel een duidelijke definitie van de begrippen 'uitsluitend recht' en 'bijzonder recht'. Een uitsluitend recht is "een recht dat bij wettelijk voorschrift of bij besluit van een bestuursorgaan aan een onderneming wordt verleend, waarbij voor die onderneming het recht wordt voorbehouden om binnen een bepaald geografisch gebied een dienst te verrichten of een activiteit uit te oefenen".41

Een bijzonder recht is "een recht dat bij wettelijk voorschrift of bij besluit van een bestuursorgaan aan een beperkt aantal ondernemingen wordt verleend en waarbij binnen een bepaald geografisch gebied: (1) het aantal van deze ondernemingen die een dienst mogen verrichten of een activiteit mogen uitoefenen op een andere wijze dan volgens objectieve, evenredige en nietdiscriminerende criteria tot twee of meer wordt beperkt, (2) verscheidene concurrerende ondernemingen die een dienst mogen verrichten of een activiteit mogen uitoefenen op een andere wijze dan volgens deze criteria worden aangewezen, of (3) aan een of meer ondernemingen die een dienst mogen 
verrichten of een activiteit mogen uitoefenen op een andere wijze dan volgens deze criteria voordelen worden toegekend waardoor enige andere onderneming aanzienlijk wordt belemmerd in de mogelijkheid om dezelfde activiteiten binnen hetzelfde geografische gebied onder in wezen gelijkwaardige voorwaarden uit te oefenen". ${ }^{2}$

In essentie is bij een uitsluitend recht dus sprake van een monopolie en bij een bijzonder recht van een oligopolie.

Voor de toepassing van het transparantiebeginsel bij de verlening van bijzondere en uitsluitende rechten is het volgende nog van belang. Uit de aanbestedingsrichtlijnen volgt niet dat voor de verlening van deze rechten een aanbesteding moet worden gehouden. ${ }^{43}$ Gelet op het feit dat de aanbestedingsrichtlijnen slechts betrekking hebben op opdrachten en niet op (eenzijdige) besluiten waarbij uitsluitende of bijzondere rechten worden verleend, leek lange tijd de stelling verdedigbaar dat aanbestedingsbeginselen, zoals het transparantiebeginsel, niet op deze verlening van toepassing zijn. Artikel 106 VWEU (voorheen artikel 86 EG-Verdrag) bepaalt echter dat lidstaten met betrekking tot ondernemingen waaraan zij bijzondere of uitsluitende rechten verlenen, geen enkele maatregel nemen of handhaven die in strijd is met de regels van de verdragen en het transparantiebeginsel vloeit rechtstreeks voort uit deze verdragen. ${ }^{\mathbf{4 4}}$ Het Hof van Justitie had eerder al geoordeeld dat, hoewel concessieovereenkomsten voor diensten niet vallen binnen de werkingssfeer van de aanbestedingsrichtlijnen, de overheden die concessieovereenkomsten sluiten wel de fundamentele regels van het VWEU in het algemeen, en in het bijzonder het beginsel van gelijke behandeling en het verbod van discriminatie op grond van nationaliteit alsmede de daaruit voortvloeiende transparantieverplichting, in acht moeten nemen. ${ }^{\mathbf{4 5}}$ Het Betfair-arrest breidt deze jurisprudentielijn uit naar de verlening van exclusieve rechten, los van de werkingssfeer van de aanbestedingsrichtlijnen.

De conclusie lijkt dan ook gerechtvaardigd dat ook bij de verlening van bijzondere en uitsluitende rechten een transparante procedure moet worden gevolgd, tenzij een van de Verdragsuitzonderingen van toepassing is. Dit blijkt ook uit het Werkdocument van de Europese Commissie betreffende de toepassing van het EU-aanbestedingsrecht op de betrekkingen tussen aanbestedende diensten ("publiek-publieke samenwerking") uit $2011 .{ }^{46}$ Hierin wordt ingegaan op de verhouding tussen aanbestedingsregels en uitsluitende rechten als bedoeld in artikel 18 van richtlijn 2004/18/EG. ${ }^{47}$ Gesteld wordt dat de bekendgemaakte wettelijke of bestuursrechtelijke bepaling verenigbaar moet zijn met de regels van het VWEU en met de regels en beginselen die hieruit voortvloeien. Deze regels en beginselen behelzen non-discriminatie, transparantie, evenredigheid, wederzijdse erkenning en de bescherming van rechten van particulieren. Een uitsluitend recht, dat per definitie de vrijheid van dienstverrichting van andere entiteiten beperkt, is alleen onder bepaalde voorwaarden gerechtvaardigd. Het uitsluitend recht moet gerechtvaardigd zijn door een uitdrukkelijk in het Verdrag genoemde uitzondering of in overeenstemming zijn met de rechtspraak van het Hof. Er moet dan sprake zijn van dwingende redenen van algemeen belang, die geschikt moeten zijn om de verwezenlijking van het nagestreefde doel te waarborgen, niet verder mogen gaan dan wat ter bereiking van dat doel noodzakelijk is en in elk geval zonder discriminatie moeten worden toegepast. ${ }^{48}$ 
Dat er in de Nederlandse praktijk lange tijd van is uitgegaan dat voor de vestiging van een exclusief recht geen passende bekendmaking hoeft plaats te vinden, is wellicht verklaarbaar als uitsluitend naar de aanbestedingsrichtlijnen en het Bao wordt gekeken. Hieruit zou kunnen worden afgeleid dat als een uitsluitend of bijzonder recht is verkregen op basis van objectieve, proportionele en non-discriminatoire criteria ${ }^{\mathbf{4 9}}$ geen sprake is van bijzondere of uitsluitende rechten als bedoeld in de aanbestedingsrichtlijnen..$^{\mathbf{5 0}}$ De regeling in de aanbestedingsrichtlijnen laat het primaire Unierecht immers onverlet, hetgeen betekent dat er op grond van het Unierecht in beginsel een transparante verdeelprocedure moet plaatsvinden. Als er geen passende bekendmaking heeft plaatsgevonden (bijvoorbeeld omdat een van de Verdragsuitzonderingen van toepassing is) dan kan er op grond van de aanbestedingsrichtlijnen een nondiscriminatieclausule gelden indien derden worden ingeschakeld. In dat geval is sprake van een bijzonder of uitsluitend recht als bedoeld in die richtlijnen.

Een laatste vraag is dan nog bij welk soort besluiten een uitsluitend of bijzonder recht gevestigd kan worden. De Awb kent immers een eigen besluitbegrip. Uit de definitie van bijzondere en uitsluitende rechten in het Bao volgt dat een uitsluitend of bijzonder recht bij wettelijk voorschrift of bij besluit van een bestuursorgaan aan een onderneming moet worden verleend. In de memorie van toelichting bij het Wetsvoorstel Aanbestedingswet 2012 wordt gesteld dat de rechten op diverse wijzen kunnen worden verleend, variërend van een wet in formele zin of ander wettelijk voorschrift tot een vergunning of andersoortig besluit van een bestuursorgaan. ${ }^{\mathbf{1 1}}$ Ook de memorie van toelichting over artikel 25a van de Mededingingswet benadrukt dat de rechten kunnen worden verleend door ieder bestuursorgaan (de rijksoverheid, de provinciale of gemeentelijke overheid, een waterschap, publiekrechtelijke bedrijfsorganisatie of een ander (zelfstandig) bestuursorgaan) en in iedere publiekrechtelijke vorm (variërend van wet in formele zin tot een vergunning van burgemeester en wethouders). $\mathbf{5}^{\mathbf{2}}$ In het verleden is betoogd dat uit het Bao volgt dat het mogelijk is om bij enkel bestuursrechtelijk besluit zonder nadere wettelijke grondslag en zonder enige vorm van (met name voorafgaande) transparantie in acht te nemen een uitsluitend of bijzonder recht te vestigen.53 Dit standpunt lijkt mij echter, zoals hiervoor uiteengezet, achterhaald. Dat een besluit niet onder de reikwijdte van de richtlijnen valt, betekent niet dat de Verdragsbeginselen niet in acht hoeven te worden genomen. Hebly stelt in dat verband dat in de praktijk aanbestedende diensten steeds vaker gebruik willen maken van de mogelijkheid van het vestigen van een exclusief recht. ${ }^{\mathbf{5 4}} \mathrm{Hij}$ vraagt zich terecht af of als met een enkel bestuursrechtelijk besluit een exclusief recht zou kunnen worden gevestigd, Verdragsrechtelijke waarborgen, zoals het transparantiebeginsel, niet te veel worden uitgehold. Ook Van Hulsteijn betoogt dat slechts onder exceptionele omstandigheden een uitsluitend recht kan worden verleend. Ook zij vraagt zich af of de verlening van een uitsluitend recht zonder enige vorm van concurrentie niet in strijd is met het VWEU. Zij betoogt dat uit artikel 17 Bao volgt dat de verlening (en niet alleen de uitvoering) van het uitsluitend recht in overeenstemming met het VWEU moet zijn. 55 Om te voorkomen dat ondernemingen met een exclusief recht gaan opereren in een markt waarbinnen voldoende aanbod c.q. concurrentie aanwezig is, pleit Hebly voor het invoeren van een 'markt-toets'.56 Een voorbeeld van de verlening van een uitsluitend recht is de gemeentelijke inzameling van afval. Dit vergunningstelsel wordt in 
paragraaf 6.5 beschreven.

Samenvattend kan worden gesteld dat de Nederlandse versie van het Betfairarrest betrekking heeft op de verlening van 'exclusieve rechten', terwijl het VWEU en de aanbestedingsrichtlijnen slechts het begrip 'uitsluitende rechten' kennen. Gelet op het feit dat in de Engelse versies van het VWEU, de aanbestedingsrichtlijnen en het Betfair-arrest wel consequent wordt gerefereerd aan de verlening van 'exclusive rights', mag ervan uit worden gegaan dat 'exclusief recht' hier als synoniem voor 'uitsluitend recht' is gebruikt. De Wksvergunning uit het Betfair-arrest voldoet ook aan de definitie van een 'uitsluitend recht' uit het Bao. Het recht is immers bij besluit van een bestuursorgaan (een vergunning) aan een onderneming verleend, waarbij voor die onderneming het recht wordt voorbehouden om binnen een bepaald geografisch gebied een dienst te verrichten of een activiteit uit te oefenen, namelijk het organiseren van kansspelen. Hieruit kan mijns inziens worden afgeleid dat het Hof van Justitie van oordeel is dat ook voor de verlening van 'exclusieve' of 'uitsluitende' rechten in beginsel een transparante verdeelprocedure moet plaatsvinden, tenzij voldaan wordt aan de in dat arrest genoemde uitzondering.

In het Betfair-arrest was sprake van een éénvergunningstelsel. Het is echter ook mogelijk dat het aantal vergunningen weliswaar wordt beperkt, doch niet tot één maar tot enkele vergunningen. Een concreet Nederlands voorbeeld is de ontheffing die wordt verleend op grond van de Winkeltijdenwet. Op grond van een winkeltijdenverordening kan een gemeenteraad bepalen dat ontheffing kan worden verleend aan bijvoorbeeld twee (of meer) supermarkten om op zondag geopend te zijn. Hetgeen hiervoor gesteld is over de verlening van exclusieve vergunningen (uitsluitende rechten) geldt mijns inziens onverkort voor de verlening van bijzondere rechten, omdat de gevolgen van deze verlening hetzelfde effect hebben als de verlening van een uitsluitend recht, namelijk dat ondernemers zonder dit recht hun dienst niet mogen verrichten. Ook deze vergunningverlening valt daarom onder de werking van artikel 56 VWEU.57

\section{Vergunningen}

Het Betfair-arrest heeft betrekking op een Wks-vergunning. Het transparantiebeginsel kan dus van toepassing zijn op een bepaald soort vergunningen. Hiervoor is al ingegaan op vergunningen waarbij een exclusief recht wordt verleend. Hierna zal ik kort nog enige opmerkingen maken over wat een vergunning is, waarbij in het bijzonder wordt ingegaan op de Dienstenrichtlijn. ${ }^{58}$ Daarna wordt ingegaan op de vraag of een vergunning onder omstandigheden "een overeenkomst onder bezwarende titel” kan zijn en daarmee voldoen aan de definitie van een concessieovereenkomst uit de Europese aanbestedingsrichtlijn.

\subsection{Wat is een vergunning?}

De rechtsfiguur 'vergunning' komt niet voor in de aanbestedingsrichtlijnen. Uit flankerende Europese regelgeving, met name de Dienstenrichtlijn, en jurisprudentie kunnen echter wel wat algemene lijnen worden afgeleid waarmee 
het Europees vergunningbegrip kan worden onderscheiden van opdrachten en concessies.

De Dienstenrichtlijn bevat een omschrijving van een 'vergunningstelsel'. 59 Onder 'vergunningstelsel' wordt verstaan: "elke procedure die voor een dienstverrichter of afnemer de verplichting inhoudt bij een bevoegde instantie stappen te ondernemen ter verkrijging van een formele of stilzwijgende beslissing over de toegang tot of de uitoefening van een dienstenactiviteit". ${ }^{60}$ In overweging (39) van de Dienstenrichtlijn wordt gesteld dat het begrip vergunningstelsel onder meer dient te duiden op "de administratieve procedures voor de verlening van vergunningen, licenties, erkenningen of concessies, en ook op de verplichting zich voor de uitoefening van de activiteit in te schrijven als beroepsbeoefenaar, zich te laten opnemen in een register, op een rol of in een databank, officieel benoemd te zijn door een instantie of een beroepskaart aan te vragen." De concessie wordt hier aangeduid als een mogelijke vorm van een vergunningstelsel, mits sprake is van een administratieve procedure. ${ }^{\mathbf{6 1}} \mathrm{De}$ Dienstenrichtlijn hanteert dus een ruim vergunningbegrip. De Dienstenrichtlijn is geïmplementeerd in de Dienstenwet. In artikel 1 van deze wet is een definitie van 'vergunning' opgenomen, namelijk: "beslissing, uitdrukkelijk of stilzwijgend, over de toegang tot of de uitoefening van een dienst".

Verwarrend is dat in de Dienstenrichtlijn wordt gesteld dat een 'concessie' een administratieve vergunning kan zijn, terwijl zoals hiervoor is besproken de aanbestedingsrichtlijnen uitgaan van de 'concessieovereenkomst'. Hier lijkt dus geen eenduidig begrippenkader te worden gehanteerd. Een mogelijke verklaring kan wellicht worden gevonden in de verschillen tussen de nationale concessiefiguren. In de Interpretatieve Mededeling wordt gesteld dat onder de Dienstenrichtlijn handelingen vallen waarmee een overheidsinstelling een machtiging of een vergunning voor een economische activiteit verleent, ook al worden die handelingen in sommige lidstaten als concessieovereenkomsten aangemerkt. $^{62}$ In dat geval zou gesteld kunnen worden dat de nationale kwalificatie van een rechtsverhouding Europeesrechtelijk niet van (doorslaggevend) belang is. Dat zou wellicht betekenen dat als in het ene land een 'concessie'stelsel aangemerkt moet worden als een 'vergunning'stelsel onder de Dienstenrichtlijn, wellicht in een ander land een vergunning moet worden gekwalificeerd als een concessieovereenkomst onder de aanbestedingsrichtlijn. Daarop wordt in de volgende paragraaf ingegaan.

Het aantal beschikbare vergunningen in de zin van de Dienstenrichtlijn kan dus beperkt zijn, maar dit hoeft niet. Artikel 10 van de Dienstenrichtlijn bepaalt dat vergunningstelsels moeten zijn gebaseerd op criteria die beletten dat de bevoegde instanties hun beoordelingsbevoegdheid op willekeurige wijze uitoefenen. Deze criteria moeten onder meer 'transparant en toegankelijk' zijn. Als het aantal beschikbare vergunningen voor een activiteit beperkt is wegens een schaarste aan natuurlijke hulpbronnen of technische mogelijkheden dan moet een selectieprocedure worden vastgesteld. Deze procedure moet 'transparant' zijn. ${ }^{63}$ De Dienstenrichtlijn beperkt de werkingssfeer van artikel 12 van de Dienstenrichtlijn dus tot schaarste aan natuurlijke hulpbronnen of technische mogelijkheden. In de vorige paragraaf ben ik ook ingegaan op het onderscheid tussen 'gewone' vergunningen en 'vergunningen voor bijzondere of uitsluitende rechten', namelijk dat bij uitsluitende of bijzondere rechten het aantal ondernemingen dat over dat recht kan beschikken op voorhand is beperkt en bij gewone vergunningen niet. De verplichting om een transparante 
selectieprocedure te organiseren is dan ook niet beperkt tot vergunningstelsels die betrekking hebben op schaarste aan natuurlijke hulpbronnen of technische mogelijkheden.

Ter voorkoming van misverstanden wijs ik erop dat ook bij de verlening van 'gewone' vergunningen, los van de werkingssfeer van de Dienstenrichtlijn, Europese randvoorwaarden gelden. Volgens vaste jurisprudentie van het Hof van Justitie kan een stelsel van een voorafgaande administratieve vergunning geen rechtvaardiging vormen voor een discretionair optreden van de nationale autoriteiten waardoor de Unievoorschriften, met name die betreffende een fundamentele vrijheid als de vrijheid van dienstverrichting, van hun nuttig effect kunnen worden beroofd. Zo'n vergunningstelsel is volgens het Hof slechts gerechtvaardigd indien het is gebaseerd op objectieve, niet-discriminerende en vooraf bekende criteria, die ervoor zorgen dat duidelijke grenzen worden gesteld aan de uitoefening door de nationale autoriteiten van hun beoordelingsbevoegdheid. ${ }^{\mathbf{6}}$ Ook voor 'gewone' vergunningen wordt deze verplichting gebaseerd op het beginsel van gelijke behandeling en de daaruit voortvloeiende transparantieverplichting. Het doel van de verplichting is echter anders. Bij een 'gewone' vergunning wordt door het in acht nemen van de transparantieverplichting een grens gesteld aan de uitoefening van de beoordelingsbevoegdheid van de autoriteiten zodat deze niet op willekeurige wijze wordt gebruikt. Om controle van de onpartijdigheid van de vergunningprocedure mogelijk te maken, is het noodzakelijk dat het besluit op een voor het publiek toegankelijke wijze wordt gemotiveerd. ${ }^{65}$ In het Betfairarrest, waar sprake is van de verlening van een exclusief recht, wordt naast de motiveringsplicht, de nadruk gelegd op de passende bekendmaking vooraf. De transparantieverplichting houdt in dat geval in dat de aan elke potentiële inschrijver een passende mate van openbaarheid moet worden gegarandeerd, zodat de vergunningverlening voor mededinging openstaat. Bij een 'gewone' vergunning speelt dit element van het transparantiebeginsel niet, omdat (blijkens het Betfair-arrest) het effect van deze vergunningverlening niet vergelijkbaar is met concessieverlening. ${ }^{\mathbf{6 6}}$

Voor Nederlandse wetgevingsjuristen vormen de Aanwijzingen voor de regelgeving (Ar) de leidraad voor het schrijven van wetgeving. Een vergunning is volgens aanwijzing 125 Ar een beschikking waarbij een bepaalde handeling wordt toegestaan. Aanwijzing 131d Ar heeft specifiek betrekking op vergunningen in de zin van de Dienstenwet. ${ }^{\mathbf{6}}$ Op de regeling in de Ar wordt in paragraaf 5 nader ingegaan.

\subsection{Kan een vergunning een concessie naar Europees aanbestedingsrecht zijn?}

Hiervoor is al ingegaan op de verlening van een exclusief recht bij vergunning (zoals bij de Wks het geval is), maar kan een vergunning onder omstandigheden ook een concessie in de zin van de aanbestedingsrichtlijnen zijn? Dit zou het geval zijn als voldaan zou worden aan de begripsomschrijving van de concessieovereenkomst in de aanbestedingsrichtlijnen en dus sprake zou zijn van een overeenkomst onder bezwarende titel.

Op zowel vergunningen waarbij een exclusief recht wordt verleend als op concessies is het transparantiebeginsel van toepassing. Zoals gesteld is de Europese Commissie echter voornemens om concessies voor diensten onder het 
toepassingsbereik van een nieuwe richtlijn over de gunning van concessieopdrachten te brengen. ${ }^{\mathbf{6 8}}$ Indien deze richtlijn in werking treedt, zouden vergunningen die voldoen aan de definitie van een concessie uit deze richtlijn aan de regels die worden gesteld in de richtlijn moeten voldoen. Hierin is dan ook het belang gelegen om te bezien of een vergunning als concessie kan worden gekwalificeerd.

In veel gevallen zal het verschil tussen een vergunning en een concessie evident zijn. Dit is het geval als de vergunningverlening niet 'schaars' is. Als eenieder die aan de voorwaarden voor vergunningverlening voldoet, de vergunning kan verkrijgen, is geen sprake van een concessie. Zowel de concessie- als de opdrachtverlening houden immers de selectie van een (markt)partij in. ${ }^{69}$ Met betrekking tot de reikwijdte van de 'opdracht' en de 'concessie' wordt vaak de nadruk gelegd op het element 'overeenkomst onder bezwarende titel'. Zo stellen Pijnacker Hordijk e.a. zich op het standpunt dat een vergunning geen concessie kan zijn, omdat geen sprake is van een overeenkomst. Een vergunning van overheidswege om bepaalde activiteiten te verrichten heeft volgens hen geen opdrachtkarakter: de overheid neemt niet het initiatief om die activiteiten te verrichten, maar bewilligt in de uitoefening van die activiteiten door de vergunningaanvrager. Het begrip concessie veronderstelt dat de overheid de uitoefening van de activiteit nodig acht, terwijl die intentie bij vergunningverlening geen gegeven is. ${ }^{\mathbf{7 0}}$ Ook in de nota van toelichting bij het $\mathrm{Bao}^{\mathbf{7 1}}$ en in de memorie van toelichting bij de Aanbestedingswet $2012^{\mathbf{7 2}^{2}}$ wordt gesteld dat geen sprake is van een overheidsopdracht wanneer middels een eenzijdige rechtshandeling (indirect) een opdracht wordt verleend, bijvoorbeeld het instellen van een dienst of het aanwijzen van een toezichthouder. Mijns inziens is echter niet uitgesloten dat onder bepaalde omstandigheden een vergunning kan worden aangemerkt als een concessieovereenkomst. Hierbij zijn twee elementen uit de definitie van de concessie uit de aanbestedingsrichtlijn van belang, namelijk 'overeenkomst' en 'bezwarende titel'.

\section{Bezwarende titel: uitvoeringsplicht}

Met de bezwarende titel wordt gedoeld op de uitvoeringsplicht. In overweging (6) van het voorstel voor een concessierichtlijn wordt gesteld dat de uitvoering van de dienst waarvoor de concessie wordt verleend onderworpen is aan specifieke door de aanbestedende dienst bepaalde bindende verplichtingen die juridisch afdwingbaar zijn. Een 'gewone' vergunning bevat normaliter geen uitvoeringsplicht. Echter, juist bij de toekenning van een (exclusief) recht worden meestal ook (uitvoerings)plichten opgelegd. De overheid kiest voor het toekennen van exclusieve rechten omdat er een publiek belang is gemoeid met de diensten of activiteiten in kwestie. Daartegenover staat een verplichting met het oog op de behartiging van dat belang. ${ }^{73}$

Ook Schlössels \& Zijlstra stellen dat het enige juridische verschil tussen een concessie en een vergunning de plicht tot het verrichten van de handeling is. ${ }^{\mathbf{7 4}}$ Dit rechtvaardigt echter de vraag of een schaarse 'vergunning' met een uitvoeringsplicht niet als concessie gekwalificeerd kan (en moet) worden. Stergiou stelt terecht dat het verstrekken van een vergunning over het algemeen genomen niet kan worden beschouwd als het verstrekken van een overheidsopdracht. Op basis van een vergunning is een onderneming bevoegd om een bepaalde (economische) activiteit te ontplooien. Een dergelijke 
toestemming is vaak niet gebaseerd op een contractuele relatie en een bezwarende titel ontbreekt in het merendeel van de gevallen, aangezien een vergunninghouder geen vergoeding ontvangt voor het verrichten van de activiteiten. ${ }^{75}$ Indien de onderneming op grond van een vergunning echter het exclusieve recht verkrijgt onder de (uitvoerings)verplichting dat de vergunde activiteit wordt verricht, is wellicht wel sprake van een concessie.

Nijhof stelt met betrekking tot de nakoming dat in het bestuursrecht onderscheid kan worden gemaakt tussen begunstigende en belastende beschikkingen. Volgens Nijhof geldt voor een begunstigende beschikking geen plicht tot nakoming, maar voor een belastende beschikking wel. Nijhof constateert naar aanleiding van een sectorenonderzoek in de post-, elektriciteits, drinkwater- en openbaar vervoersmarkt dat materieel sprake is van concessies maar dat de jure gekozen wordt voor (eenzijdige) bestuursrechtelijke rechtsfiguren. De verplichting tot nakoming wordt ofwel in de vergunning ofwel in de wet in formele zin opgenomen. Er ontstaat hierbij een rechtsfiguur die zowel een begunstigend als belastend element heeft. ${ }^{\mathbf{6}}$ Danker-Hagenaars (die uitgaat van een historisch concessiebegrip) betoogt dat een concessie wordt verleend ter behartiging van een algemeen belang en bestemd is tot gebruik door het publiek. Dit uitgangspunt rechtvaardigt volgens haar het opleggen van een uitvoeringsplicht en daarmee onderscheidt de concessie zich van andere publiekrechtelijke rechtsfiguren. ${ }^{77}$

Indien naast de vergunningverlening ook een uitvoeringsovereenkomst gesloten wordt, kan nakoming van de overeenkomst worden gevorderd en is zonder twijfel sprake van een bezwarende titel. De vraag is dan hoe een uitvoeringsplicht die bij wettelijk voorschrift of vergunningvoorschrift wordt opgelegd, moet worden gekwalificeerd. Een aanknopingspunt zou het door Zijlstra bepleite terminologische onderscheid tussen 'burgerplichten' en 'burgerlasten' kunnen zijn. Voor een 'burgerlast' zou dan aangesloten kunnen worden bij het Duitse begrip ‘Obliegenheiten'. Een Obliegenheit is ‘de gehoudenheid zich in een bepaalde situatie jegens een ander op een bepaalde wijze te gedragen op straffe van verval of beperking van toekomende rechten of bevoegdheden. Als een activiteit waarvoor een subsidie is verleend, niet wordt verricht, kan geen nakoming worden gevorderd. De subsidie kan 'slechts' lager worden vastgesteld en teruggevorderd worden. Er is dan dus geen sprake van een burgerplicht, maar van een burgerlast. Indien echter naast het subsidiebesluit ook een uitvoeringsovereenkomst wordt gesloten, kan wel nakoming worden gevorderd. Ook als de niet-naleving van een voorwaarde met een bestuurlijke boete of een dwangsom zou kunnen worden gehandhaafd, verandert de last volgens Zijlstra in een rechtsplicht. ${ }^{\mathbf{8}}$ De uitvoeringsplicht die bij wettelijk voorschrift of vergunningvoorschrift wordt opgelegd, zal in beginsel handhaafbaar zijn en is daarmee een burger- of rechtsplicht. Mijns inziens is dan ook verdedigbaar dat in een dergelijk geval sprake is van een 'bezwarende titel'.

\section{Overeenkomst}

Uit zowel de eerdergenoemde Interpretatieve Mededeling als jurisprudentie van het Hof van Justitie volgt dat het begrip 'overeenkomst' materieel moet worden uitgelegd, ongeacht de juridische kwalificatie in het nationale recht. In de Interpretatieve Mededeling wordt gesteld dat iedere overheidshandeling, of het nu gaat om een eenzijdige handeling of om een contract, waarbij voorwaarden 
voor een economische prestatie worden vastgelegd, moet voldoen aan de regels en beginselen van het VWEU.79 In de mededeling worden eenzijdige rechtshandelingen dus uitdrukkelijk wel onder de reikwijdte van een 'concessieovereenkomst' gebracht, mits het eenzijdige rechtshandelingen waarmee de derde heeft ingestemd betreft.

Ook uit het Scala-arrest volgt dat het begrip 'overeenkomst' ruim moet worden uitgelegd. ${ }^{80}$ In dit arrest wordt ingegaan op het belang van het bestaan van een overeenkomst, omdat werd betwist dat daarvan sprake zou zijn. De ontwikkeling werd namelijk (deels) bij (regionale) wet vastgelegd. Het Hof constateert echter dat de wettelijke bepalingen het bestaan van het contractuele element als bedoeld in de aanbestedingsrichtlijn niet kunnen uitsluiten. ${ }^{\mathbf{8 1}}$ De omstandigheid dat de verkavelingsovereenkomst onder het publiekrecht viel en was gesloten in het kader van de uitoefening van overheidsgezag, verzette zich niet tegen het bestaan van het contractuele element, maar pleitte zelfs daarvoor. In verschillende lidstaten is de overeenkomst tussen een aanbestedende dienst en een aannemer namelijk een administratiefrechtelijke overeenkomst die als zodanig onder het publiekrecht valt. Ten slotte overweegt het Hof dat deze uitleg strookt met het belangrijkste doel van de richtlijn, te weten de openstelling van overheidsopdrachten voor de uitvoering van werken voor de mededinging. ${ }^{\mathbf{8 2}}$ Naast het Scala-arrest zijn ook de arresten Asemfo en Correos interessant. Het Hof oordeelt in het Asemfo-arrest dat geen sprake is van een overeenkomst als de onderneming geen enkele vrijheid heeft om een door de bevoegde instanties verstrekte opdracht al dan niet uit te voeren of om het op haar diensten toe te passen tarief te bepalen. ${ }^{\mathbf{8 3}}$ Het Hof heeft dit genuanceerd in het Correos-arrest door te stellen dat deze redenering wel in haar specifieke context moet worden gelezen. In het Correos-arrest was het exclusieve recht voor leveren van postdiensten niet neergelegd in een overeenkomst maar in de wet inzake overheidsopdrachten en een daaruit voortvloeiende samenwerkingsovereenkomst. De Spaanse regering betoogde dat geen sprake kon zijn van een concessieovereenkomst, omdat Correos het sluiten van de samenwerkingsovereenkomst niet kon weigeren. Volgens het Hof heeft Correos als leverancier van de universele postdienst een geheel andere taak. Deze betrekking moet als contractueel worden gekwalificeerd. Slechts als de gesloten overeenkomst in werkelijkheid een eenzijdige bestuurshandeling zou zijn waarbij alleen ten laste van Correos verplichtingen worden opgelegd, dus een handeling die aanzienlijk zou afwijken van de normale voorwaarden van het commerciële aanbod van deze onderneming, zou moeten worden geconcludeerd dat een overeenkomst ontbreekt. Hiertoe is met name van belang of Correos de mogelijkheid heeft om met het ministerie te onderhandelen over de concrete inhoud van de te leveren prestaties en de daarop toepasselijke tarieven en of deze onderneming zich van de uit de samenwerkingsovereenkomst voortvloeiende verplichtingen kan bevrijden, op voorwaarde dat de hierin voorziene opzegtermijn wordt nageleefd. ${ }^{\mathbf{8 4}}$ Ook in de arresten Stoss ${ }^{\mathbf{8 5}}$ en Anomar 86

Met betrekking tot de vraag of eenzijdige rechtshandelingen ook onder het concessiebegrip kunnen vallen zijn ook overwegingen (21) en (22) van het voorstel voor een concessierichtlijn interessant. In deze overwegingen wordt gesteld dat bij persoonsgebonden diensten, zoals bepaalde diensten op sociaal-, gezondheids- en onderwijsgebied, wegens het belang van de culturele context en het gevoelige karakter van deze diensten, lidstaten vrij blijven om deze diensten 
zelf te verrichten of om sociale diensten zo te organiseren dat er geen sprake is van gunning van overheidsopdrachten, bijvoorbeeld door deze diensten alleen te financieren of door licenties of machtigingen te verlenen aan alle ondernemers die beantwoorden aan de vooraf door de aanbestedende dienst of aanbestedende entiteit vastgestelde voorwaarden, zonder beperkingen of quota, op voorwaarde dat dit systeem voor voldoende publiciteit zorgt en aan de beginselen van transparantie en non-discriminatie voldoet.

Het is niet altijd eenvoudig om te bepalen wanneer sprake is van een concessieovereenkomst. Hiervoor is al gewezen op de Interpretatieve Mededeling waarin wordt gesteld dat zij geen betrekking heeft op onder andere "handelingen waarmee een overheidsinstelling een machtiging of een vergunning voor een economische activiteit verleent, ook al worden die handelingen in sommige lidstaten als concessieovereenkomsten aangemerkt”. Als voorbeelden van dergelijke vergunningen worden taxivergunningen, vergunningen voor het gebruik van de openbare weg (krantenkiosken, caféterrassen) en rechtshandelingen met betrekking tot apotheken en benzinepompen genoemd. ${ }^{\mathbf{8}}$ Ik vermoed dat de Europese Commissie hiermee heeft willen stellen dat een 'gewone' vergunning (oftewel een vergunning die eenieder die aan de voorwaarden voldoet kan verkrijgen) niet onder de werkingssfeer van de mededeling valt, ook niet als in een lidstaat deze toestemming een concessieovereenkomst wordt genoemd. De door de Europese Commissie genoemde voorbeelden zijn echter niet per definitie 'gewone' vergunningen. Zo was de taximarkt in Nederland lange tijd gesloten. Ten slotte kan een parallel getrokken worden met het ambtenarenrecht. Het ambtenarenrecht is formeel ook eenzijdig, maar vormt materieel een tweezijdige rechtsbetrekking. Wilsovereenstemming is formeel niet vereist, maar moeilijk voorstelbaar is dat iemand tegen zijn wil wordt aangesteld als ambtenaar. ${ }^{\mathbf{8 8}}$ Gesteld kan worden dat het concessiebesluit het karakter van een 'acte negocié' heeft. ${ }^{89}$ Ook dit illustreert dat een eenzijdige rechtshandeling een concessieovereenkomst kan zijn, mits deze rechtshandeling van de overheid wordt aanvaard door de concessiehouder.

Uit het voorgaande kan worden afgeleid dat een vergunning onder omstandigheden kan worden aangemerkt als een overeenkomst onder bezwarende titel. Als met de vergunningverlening ook een recht wordt verleend, wordt aan alle elementen van een 'concessie' zoals omschreven in de aanbestedingsrichtlijnen, voldaan. Dit kan in het bijzonder het geval zijn bij schaarse vergunningen waaraan een uitvoeringsplicht is verbonden.

\subsection{Tussenconclusie}

Een concessie is op grond van de Europese aanbestedingsrichtlijnen een overeenkomst onder bezwarende titel waarbij de tegenprestatie voor de te verlenen diensten bestaat uit de verlening van een recht. Bij schaarse vergunningverlening wordt eveneens een recht verleend. Zo wordt het verbod om kansspelen aan te bieden, doorbroken door aan één of enkele partijen dit exploitatierecht te verlenen. Onder omstandigheden kan een vergunning worden aangemerkt als een overeenkomst onder bezwarende titel. Dit is het geval wanneer het aantal mogelijke vergunninghouders beperkt wordt en er een uitvoeringsplicht aan de vergunning wordt verbonden. Hoewel strikt genomen sprake is van een éénzijdige rechtshandeling, is moeilijk voorstelbaar dat aan 
een marktpartij tegen zijn wil een vergunning wordt verleend. Een partij zal de vergunning aanvragen en op basis van die aanvraag worden geselecteerd. Vervolgens wordt de vergunning (met uitvoeringsplicht) verleend. Indien de vergunninghouder geen bezwaarschrift indient, kan dit worden geïnterpreteerd als de aanvaarding van de vergunning en daarmee de plicht om het recht uit te voeren.

Indien een vergunning niet kan worden aangemerkt als een tweezijdige rechtshandeling of anderszins niet voldoet aan de elementen van de definitie van een 'concessieovereenkomst', dan zou het eenzijdige besluit wellicht kunnen worden aangemerkt als een 'bijzonder of uitsluitend recht' als bedoeld in de aanbestedingsrichtlijnen. Een uitsluitend recht is een recht dat bij besluit van een bestuursorgaan aan een onderneming wordt verleend, waarbij voor die onderneming het recht wordt voorbehouden om binnen een bepaald geografisch gebied een dienst te verrichten of een activiteit uit te oefenen.

Bij vergunningen die worden verleend op grond van de Wks komen zowel vergunningen met als zonder uitvoeringsplicht voor. In de Beschikking Staatsloterij is bepaald dat ten minste tien maal per jaar de staatsloterij gehouden moet worden. In andere kansspelvergunningen is geen uitvoeringsplicht opgenomen.90 ${ }^{\mathbf{9 0}}$ Deze vergunningen bevatten slechts een maximaal en geen minimaal aantal te organiseren kansspelen. Dat betekent dat de Beschikking Staatsloterij mijns inziens voldoet aan de definitie van een concessie. De andere kansspelvergunningen voldoen niet aan de definitie van een concessie. Wel is sprake van besluiten waarbij een exclusief recht wordt verleend.

Uit onder andere het Betfair-arrest kan worden afgeleid dat voor zowel concessieverlening als de verlening van vergunningen waarbij exclusieve (of uitsluitende) rechten worden verleend, een transparante selectieprocedure georganiseerd moet worden, tenzij de in het arrest genoemde uitzondering van toepassing is. Als het voorstel voor een concessierichtlijn doorgang vindt, zullen vergunningen die voldoen aan de definitie van een concessie uit deze richtlijn ook aan de regels die worden gesteld in die richtlijn moeten voldoen.

\section{Wijziging van de Aanwijzingen voor de regelgeving?}

In het voorgaande is gekeken onder welke omstandigheden het nodig is een transparante verdeelprocedure te organiseren voor vergunningverlening. Hiervoor is onder meer gekeken naar de (Europeesrechtelijke) rechtsfiguren 'opdracht', 'concessie' en 'vergunning'. In het Nederlandse bestuursrecht worden de Ar vaak als uitgangspunt genomen om te bepalen welk rechtsfiguur geëigend is om verboden en geboden vorm te geven. In de Ar worden de vergunning, vrijstelling, ontheffing en erkenning onderscheiden.

Een vergunning is volgens de Ar een beschikking waarbij een bepaalde handeling wordt toegestaan. ${ }^{\mathbf{9 1}}$ Hiervoor is al gewezen op Aanwijzing 131d Ar. Deze aanwijzing heeft specifiek betrekking op vergunningen in de zin van de Dienstenwet.92

Een vrijstelling is volgens de Ar een besluit waarbij een uitzondering op een wettelijk verbod of gebod wordt gemaakt voor een categorie van gevallen.93 Een ontheffing is volgens de Ar een beschikking waarbij in een individueel geval een uitzondering op een wettelijk verbod of gebod wordt gemaakt.94 Een erkenning is volgens de Ar een beschikking waarbij wordt vastgesteld dat 
een persoon of instelling aan bepaalde eisen voldoet.95

De Ar noemt de figuur van de concessie niet. In paragraaf 3.3 is ingegaan op de betekenis van het begrip op grond van de Europese aanbestedingsrichtlijnen. In Nederland worden verschillende omschrijvingen aan het concessiebegrip gegeven. Schlössels \& Zijlstra omschrijven een concessie als een handeling die de overheid in het algemeen belang noodzakelijk acht en deze onder bepaalde voorwaarden door een particulier laat verrichten; deze laatste is niet alleen toegestaan, maar ook verplicht de activiteit te verrichten. Het enige juridische verschil tussen een concessie en een vergunning is volgens Schlössels \& Zijlstra de plicht tot het verrichten van de handeling.96

Danker-Hagenaars heeft onderzoek gedaan naar de historische wortels van de concessie in Nederland. ${ }^{\mathbf{9 7}}$ Hieruit blijkt dat onderscheid werd gemaakt tussen de 'eigenlijke concessie' of bedrijfsconcessie en de 'oneigenlijke concessie' of gebruiksconcessie. De eigenlijke concessie zou een publiekrechtelijk karakter hebben. Het betreft een bijzondere 'vergunning' waarbij toestemming wordt verleend tot het verrichten van een handeling die in het algemeen belang wenselijk wordt geacht. De oneigenlijke concessie betreft een overeenkomst voor het verrichten van activiteiten op overheidsgronden (bijvoorbeeld het aanleggen van buisleidingen). 98

Nijhof stelt dat voor de concessie geldt dat de overheid de handeling niet afwijst (waarvoor de ontheffing bedoeld is), maar er ook geen neutrale positie over inneemt (waarvoor de vergunning bedoeld is). Bij concessieverlening streeft de overheid de handeling juist na en acht de handeling in het algemeen wenselijk, maar overheidsregulering is noodzakelijk door marktfalen. Een concessie is daardoor volgens Nijhof te vergelijken met een subsidie. Ook bij een subsidie wil de overheid een activiteit stimuleren, maar bij een concessie wordt de uitvoering van de activiteit verplicht. Een subsidie met een uitvoeringsovereenkomst is dan ook volgens Nijhof vergelijkbaar met een concessie. 99

Als gezegd noemt de Ar de figuur van de concessie niet. Dit is van belang, nu wel wordt gesteld dat het gebruik van andere termen voor de vier hiervoor genoemde figuren vergunning, vrijstelling, ontheffing en erkenning (zoals toestemming, instemming of verlof) moet worden vermeden. Gelet op het feit dat de aanbestedingsrichtlijnen deze rechtsfiguur wel kennen, kan dit tot gevolg hebben dat op grond van de Ar een vergunningstelsel in het leven wordt geroepen, terwijl voldaan wordt aan de Unierechtelijke begripsomschrijving van een concessie. Dit is het geval bij schaarse vergunningen met een uitvoeringsplicht. In dit verband wijs ik ook op Schlössels \& Zijlstra die stellen dat nu 'concessie' geen wettelijk vastgelegd begrip is, het niet overal in de wetgeving dezelfde betekenis heeft. Zo kan een gemeentelijke verordening die voor het exploiteren van een rondvaartbedrijf een vergunning eist, gekoppeld aan een uitvoeringsovereenkomst die voorziet in een plicht tot het verzorgen van de dienst, materieel als concessiestelsel worden beschouwd. ${ }^{\mathbf{1 0 0}}$ Dit is volgens mij inderdaad een goed voorbeeld van een concessiestelsel, waarbij ik ervan uitga dat de gemeente het aantal beschikbare exploitatievergunningen voor rondvaartbedrijven beperkt heeft en er dus een vorm van schaarste is. Naar aanleiding van het Betfair-arrest rijst de vraag of deze exploitatievergunning dan ook niet door middel van een transparante verdeelprocedure moet worden verleend.

Danker-Hagenaars schreef in 2000 dat het gebruik van het woord 'concessie' in 
Nederland op historische gronden (en onder invloed van het Franse rechtsstelsel) verklaarbaar was, terwijl juridisch systematisch gezien het woord 'vergunning' wellicht beter op zijn plaats zou zijn. ${ }^{101}$ Anno 2012 is mijns inziens eerder het omgekeerde het geval: mede op basis van de Ar wordt gekozen voor een 'vergunning', terwijl het begrip 'concessie' vanuit Europees perspectief soms te prefereren valt.

Over het rechtskarakter van de concessie betogen Schlössels \& Zijlstra dat een concessie krachtens privaatrechtelijke bevoegdheid (met name het eigendomsrecht) beter geen concessie genoemd kan worden, net zoals het onwenselijk zou zijn om over 'privaatrechtelijke vergunningen' te spreken. ${ }^{\mathbf{1 0 2}}$ Naar mijn mening zouden een privaatrechtelijke concessieovereenkomst en een publiekrechtelijk concessiebesluit naast elkaar kunnen bestaan, mits beide materieel overeenkomen met het concessiebegrip uit de aanbestedingsrichtlijnen. Ik zou er daarom voor willen pleiten om het concessiebesluit als rechtsfiguur toe te voegen aan de Ar. Deze omschrijving zou zoveel mogelijk moeten aansluiten bij het materiële concessiebegrip uit Richtlijn 2004/18/EG en de toekomstige concessierichtlijn. Gedacht zou kunnen worden aan: 'een concessie is een besluit dat de uitvoering van werken of de verrichting van diensten als voorwerp heeft, waarbij de tegenprestatie voor de uit te voeren werken of diensten bestaat hetzij uitsluitend in het recht het werk of de dienst, te exploiteren, hetzij in dit recht, gepaard gaande met een prijs, en waarbij de concessiehouder verplicht wordt de werken of diensten uit te voeren'. Hierdoor zouden alle rechtsfiguren die materieel aan deze omschrijving voldoen, ongeacht hun (publiek- of privaatrechtelijke) rechtskarakter, aangeduid worden als 'concessie'.

Besluiten die niet aan deze omschrijving van een concessie voldoen, zullen wel aan de omschrijving van een 'vergunning' of 'ontheffing' voldoen. Door middel van deze besluiten kunnen een uitsluitend of bijzonder recht worden verleend. Bij deze verlening zal het transparantiebeginsel in acht moeten worden genomen. Het zou wenselijk zijn als bij de invoering van een dergelijk stelsel expliciet in de toelichting wordt gesteld dat sprake is van een vergunningstelsel dat de verlening van een uitsluitend of bijzonder recht mogelijk maakt.

\section{Enkele concrete voorbeelden}

Is de Wet op de kansspelen nu een uniek stelsel waardoor de gevolgen van het Betfair-arrest beperkt zijn of zijn er meer Nederlandse vergunningstelsels die onder de werking van het Betfair-arrest zouden kunnen vallen? Zijn er vergunningstelsels die eigenlijk aangemerkt kunnen worden als concessie en die niet transparant worden verdeeld? Zijn er 'exclusieve' vergunningstelsels die hetzelfde effect hebben als een concessie en daarom volgens het criterium van het Hof van Justitie in het Betfair-arrest transparant moeten worden verdeeld? Om de wat theoretische beschrijving uit de vorige paragrafen enigszins te concretiseren, zal ik hierna enkele voorbeelden van vergunningstelsels beschrijven die wellicht transparant zouden moeten worden verdeeld. Volledigheidshalve wijs ik erop dat, zoals in paragraaf 3.1 al is toegelicht, voor de vraag naar de mogelijke gevolgen van het Betfair-arrest, het Unierecht waaruit het transparantiebeginsel voortvloeit, niet van toepassing is bij zuiver interne situaties, maar dat de vraag wanneer hier sprake van is niet te terughoudend mag worden beantwoord. In de voorbeelden die hierna worden gegeven, wordt 
er vanuit gegaan dat hieraan voldaan is.

Een aantal van de voorbeelden die hierna worden gegeven betreft vergunningstelsels die (gedeeltelijk) Europees zijn gereguleerd en een aantal is juist geheel gebaseerd op nationale (zelfs decentrale) regelgeving. Eerst zal ingegaan worden op de kansspelvergunning. Vervolgens zal ingegaan worden op de volgende (gedeeltelijk) Europese vergunningstelsels: de frequentievergunning en de concessie om openbaar vervoer te mogen verrichten op grond van de Wp200o. Ten slotte wordt ingegaan op de volgende drie nationale vergunningstelsels: de rechten die worden verleend om een tankstation te mogen exploiteren en daar energieoplaadpunten te mogen plaatsen, de ontheffingen die op grond van de Winkeltijdenwet worden verleend en ten slotte de gemeentelijke aanwijzing van een afvalinzameldienst.

\subsection{Wet op de kansspelen}

Allereerst de kansspelvergunning. Hoe zou een kansspelvergunning kunnen worden gekwalificeerd? Indien gekeken wordt naar de door Schlössels en Zijlstra gehanteerde indeling dan zou eigenlijk sprake zijn van een ontheffing. ${ }^{\mathbf{1 0 3}}$ Gokverslaving wordt door de Nederlandse overheid immers onwenselijk geacht. Zou de kansspelvergunning ook kunnen worden aangemerkt als een concessie? Opvallend is dat bij vergunningen die worden verleend op grond van de Wks, zowel vergunningen met als zonder uitvoeringsplicht voorkomen. In de Beschikking Staatsloterij is bepaald dat ten minste tien maal per jaar de staatsloterij gehouden moet worden. Dat betekent dat de Beschikking Staatsloterij mijns inziens voldoet aan de definitie van een concessie. In andere kansspelvergunningen is geen uitvoeringsplicht opgenomen. ${ }^{\mathbf{1 0 4}}$ Deze vergunningen bevatten slechts een maximaal en geen minimaal aantal te organiseren kansspelen. Ook in de Wks zelf is geen uitvoeringsplicht opgenomen. De Lotto (en andere vergunninghouders) zijn niet verplicht om een bepaald (minimum)aantal kansspelen per jaar te organiseren. De ratio hiervoor zou kunnen zijn gelegen in het feit dat het exploiteren van kansspelen in Nederland niet in het algemeen belang wordt geacht, maar juist wordt gereguleerd om onder andere gokverslaving te voorkomen. Hier is dan ook sprake van een vergunning waarbij exclusief recht is verleend.

Uit het Betfair-arrest volgt dat een verdeelprocedure voor de verlening van een dergelijk recht in beginsel transparant moet zijn. De Afdeling heeft vervolgens geconcludeerd dat de besluiten tot verlening van de vergunningen aan De Lotto en SGR en de besluiten tot weigering de vergunningen aan Betfair te verlenen in strijd waren met artikel 49 van het EG-Verdrag, zoals dat verdragsartikel is uitgelegd door het Hof van Justitie in het Betfair-arrest. Een wetsvoorstel om de Wks te wijzigen met inachtneming van de uitspraak van de Afdeling en het arrest van het Hof is nog niet bij de Tweede Kamer ingediend. ${ }^{105}$

\subsection{Telecommunicatiewet en de Wp2000}

Bekende andere voorbeelden van wetten in formele zin die het aantal beschikbare vergunningen beperken zijn de Telecommunicatiewet en de Wp200o. Beide wetten komen uitgebreid aan de orde in de proefschriften van Nijhof en Danker-Hagenaars. In dit artikel volsta ik daarom met een paar korte opmerkingen; verder verwijs ik graag naar genoemde dissertaties. 
De meest recente veilingprocedure op grond van de Telecommunicatiewet is op 16 april 2012 begonnen. Het betreft 41 frequentievergunningen voor het gebruik van de frequentieruimte in de frequentiebanden 800,900 en $1800 \mathrm{MHz} .{ }^{106} \mathrm{De}$ winnaar van de veiling zal het gebruiksrecht verkrijgen op die frequentieruimte. Hij zal daarvoor een prijs moeten betalen. In de vergunning zal een ingebruiknameverplichting worden opgenomen. Deze ingebruiknameverplichting behelst de verplichting voor de vergunninghouder om de openbare elektronische communicatiedienst aan te bieden en de verplichting om dat in een gebied met een zekere omvang te doen. De verplichting waarborgt daarmee dat vergunninghouders ook daadwerkelijk door middel van de aan hen vergunde frequenties commercieel actief worden en er een dienst mee aanbieden. Aan de vergunning wordt dus de verplichting opgenomen om binnen een bepaalde tijd het netwerk uit te rollen over (geheel of een deel van) Nederland. ${ }^{\mathbf{1 0}}$ De frequentievergunning voldoet dus aan alle elementen van een concessie(overeenkomst).

Op grond van de Wp200o wordt bij besluit een concessie verleend. ${ }^{\mathbf{1 0 8}}$ Een concessie is in de Wp200o gedefinieerd als een 'recht om met uitsluiting van anderen openbaar vervoer te verrichten in een bepaald gebied gedurende een bepaald tijdvak' ${ }^{109}$ Uitsluitend de concessiehouder is bevoegd om het in het concessiebesluit beschreven openbaar vervoer te verrichten. De tweezijdigheid van een concessiebesluit blijkt uit artikel 29a Wp2000 waarin wordt gesteld dat een besluit tot verlening of wijziging van een concessie zonder dat daartoe een aanbesteding is gehouden, kan worden genomen indien de vervoerder niet binnen vier dagen na de dag waarop het voorgenomen besluit aan hem is bekendgemaakt aan de concessieverlener heeft doen blijken dat hij de concessie niet zonder voorbehoud aanvaardt. De uitvoeringsplicht is gecodificeerd in artikel 34 Wp2000. Dit artikel bepaalt dat de concessiehouder verplicht is openbaar vervoer te verrichten volgens hetgeen in de concessie is bepaald en verplicht is de daaraan verbonden voorschriften na te leven. Ook deze regeling voldoet dus aan alle elementen van een concessie(overeenkomst).

\subsection{Wet tot veiling van bepaalde verkooppunten van motorbrandstoffen}

Een eerste voorbeeld van een zuiver nationaal vergunningstelsel dat wellicht moet worden aangemerkt als een concessiestelsel, biedt de Wet tot veiling van bepaalde verkooppunten van motorbrandstoffen. Op grond van artikel 26 van de onderliggende Regeling veiling benzinestations langs rijkswegen verleent de directeur Domeinen ${ }^{\mathbf{1 1 0}}$ het huurrecht aan de deelnemer die het hoogste bod op een huurrecht heeft uitgebracht, nadat de verschuldigde bedragen zijn voldaan. Daartoe sluit de directeur Domeinen een huurovereenkomst. Deze overeenkomst heeft een maximale looptijd van 15 jaren. In de memorie van toelichting wordt gesteld dat voor het in gebruik geven van grond voor het vestigen van een verkooppunt van motorbrandstoffen uiteenlopende aanduidingen werden gebruikt, zoals 'concessie' en 'privaatrechtelijke vergunning'. In de wet is gekozen voor een huurovereenkomst, waarmee (volgens de memorie van toelichting) duidelijk wordt dat de rechtsverhouding tussen de Staat en de gebruiker van de locatie een zuiver privaatrechtelijk karakter heeft en de Staat hier handelt als eigenaar van de grond en dus in zijn 
privaatrechtelijke hoedanigheid. ${ }^{\mathbf{1 1 1}}$ In het verlengde hiervan is het opvallend hoe thans de verzorgingsplaatsen van oplaadpunten voor elektrische auto's worden verdeeld. Rijkswaterstaat heeft bepaald dat het plaatsen van een oplaadpunt een activiteit langs een rijksweg is waarvoor een vergunning op grond van de Wet beheer rijkswaterstaatswerken (Wbr) nodig is. Een dergelijke Wbr-vergunning zal uitsluitend worden verleend voor 459 door Rijkswaterstaat aangewezen verzorgingsplaatsen. Deze vergunning zal, in aansluiting op de 'concessieduur' (sic!) van servicestations, worden verleend met een maximale looptijd van 15 jaar. In de Kennisgeving Wijziging Voorzieningen op verzorgingsplaatsen langs rijkswegen (energielaadpunten) is een verdeelprocedure neergelegd. ${ }^{\mathbf{1 1 2}}$ Elektrisch rijden en daarmee de exploitatie van een oplaadpunt acht Rijkswaterstaat, blijkens de toelichting bij de kennisgeving, in het algemeen belang noodzakelijk. Om deze ontwikkeling te stimuleren is bepaald dat als een oplaadpunt binnen 1,5 jaar niet gebruiksgereed is, de vergunning vervalt. In paragraaf 4.2 is ingegaan op het onderscheid tussen burgerplichten en -lasten.

Het vervallen van een vergunning kan worden aangemerkt als een burgerlast. Er is echter geen uitvoeringsplicht opgenomen. Betwijfeld moet dan ook worden of sprake is van een bezwarende titel en dus van een concessie. De vergunning heeft dan ook het karakter van een vergunning waarbij een bijzonder recht wordt verleend. De gevolgen van de vergunningverlening zijn dan ook vergelijkbaar met het verlenen van een concessieovereenkomst voor diensten, omdat de vergunningverlening aan de één (of aan 459) de uitsluiting van anderen tot gevolg heeft. Het is dan ook terecht dat Rijkswaterstaat een kennisgeving in de Staatscourant heeft gepubliceerd zodat eenieder ermee bekend kon zijn dat voor 16 januari 2012 een aanvraag moest worden ingediend.

\subsection{Winkeltijdenwet}

Naast exclusieve vergunningstelsels in wetten in formele zin, kan ook schaarste worden gecreëerd bij gemeentelijke verordening. Hiervoor is al gewezen op de winkeltijdenverordeningen op grond waarvan het college van burgemeester en wethouders ontheffing kan verlenen aan één of enkele supermarkten om op zondag geopend te zijn. ${ }^{\mathbf{1 1 3}}$ Door de ontheffingverlening wordt de ene supermarkt bevoordeeld ten opzichte van andere supermarkten. Daarom is verdedigbaar dat, in lijn met het Betfair-arrest, alle potentiële supermarktexploitanten in aanmerkingen moeten kunnen komen voor deze ontheffing en dat de toedeling daarvan op een transparante wijze moet plaatsvinden. Het hangt van de bepalingen in de diverse gemeentelijke verordeningen af of de ontheffing ook kan worden aangemerkt als een concessie. Iedere gemeente kan immers voor zich bepalen of er een uitvoeringsplicht aan de ontheffingverlening wordt gekoppeld.

Over Winkeltijdenwetontheffingen is veel jurisprudentie van het College van Beroep voor het bedrijfsleven (CBb). Uit vaste jurisprudentie volgt dat aan de toekenning van een schaarse ontheffing (zoals op grond van de Winkeltijdenwet) onder meer uit een oogpunt van rechtszekerheid zware eisen dienen te worden gesteld. Deze zware eisen vertonen gelijkenis met het transparantiebeginsel.114

\subsection{Wet milieubeheer: gemeentelijke afvalinzameling}

Een laatste voorbeeld van een nationaal vergunningstelsel dat eigenlijk 
gekwalificeerd kan worden als een concessiestelsel dan wel een besluit waarbij een exclusief recht wordt verleend, is de gemeentelijke inzameling van afval. Op grond van de Wet milieubeheer (artikel 10.21 Wm) draagt het college van burgemeester en wethouders zorg voor de inzameling van huishoudelijke afvalstoffen. Artikel 10.24 Wm bepaalt dat de gemeentelijke afvalstoffenverordening ten minste regels bevat omtrent het overdragen of het ter inzameling aanbieden van huishoudelijke afvalstoffen aan een bij of krachtens de verordening aangewezen inzameldienst. ${ }^{\mathbf{1 1 5}}$ Op 18 november 2011 heeft de Hoge Raad geoordeeld over de vraag of een dergelijke aanwijzing aanbestedingsplichtig is. ${ }^{\mathbf{1 1 6}}$ In de afvalstoffenverordening van de gemeente Westland wordt bepaald dat het college van burgemeester en wethouders een inzameldienst aanwijst. Het college heeft de NV Huiscentrale Noord-Holland (HVC), een overheidsbedrijf, aangewezen als afvalinzamelaar. AVR (een private onderneming) is van mening dat deze aanwijzing aanbesteed had moeten worden en heeft een civiel kort geding gestart gericht tegen de afvalinzamelovereenkomst tussen HVC en de gemeente en een bestuursrechtelijke procedure tegen het aanwijzingsbesluit. De Hoge Raad oordeelt (kort samengevat) dat aan HVC een uitsluitend recht als bedoeld in artikel 17 Bao is verleend. ${ }^{\mathbf{1 1 7}}$ Daarom hoefde volgens de Hoge Raad in dit geval verder niet aan het EU-recht te worden getoetst. Als we nu kijken naar het Betfair-arrest valt op dat hier sprake is van een overheidsbedrijf: alle gemeenten waar het afval wordt ingezameld, zijn ook aandeelhouder van HVC. Ook in het Betfair-arrest wordt overwogen dat als een vergunning zou worden verleend "een openbare exploitant wiens beheer onder rechtstreeks toezicht staat van de Staat of een particuliere exploitant op wiens activiteiten de overheid een strenge controle kan uitoefenen" de toekenning of de verlenging van exclusieve rechten voor de exploitatie van kansspelen ten gunste van één exploitant, zonder oproep tot mededinging, niet onevenredig is. De vragen of de Teckal-doctrine en dit toezichtcriterium verschillende criteria zijn en in hoeverre HVC aan dit criterium voldoet, zijn interessante vragen, maar gaan het bestek van dit artikel te buiten. Voor hier wil ik de casus wat veranderen: stel nu dat de gemeente Westland de afvalinzameling niet zou hebben opgedragen aan een overheidsbedrijf, maar aan een private partij. Zou een rechter dan tot een ander oordeel moeten komen? Allereerst is dan de vraag hoe de rechtsverhouding tussen de gemeente en inzamelaar gekwalificeerd moet worden. Is sprake van een aanwijzingsbesluit met uitvoeringsovereenkomst of van een inzamelovereenkomst met een voorbereidingsbesluit? Gelet op de wettelijke regeling in de Wet milieubeheer, waarin een aanwijzingsbevoegdheid is geattribueerd, acht ik de eerste optie aannemelijker. ${ }^{\mathbf{1 1 8}}$ Vervolgens is de vraag of dit aanwijzingsbesluit materieel voldoet aan de kenmerken van een concessiebesluit dan wel dat sprake is van een besluit waarbij een exclusief (of uitsluitend) recht wordt verleend en dat hetzelfde effect heeft als een concessieverlening. ${ }^{\mathbf{1 1 9}}$ Dit zal, net als bij de Winkeltijdenwet, afhankelijk zijn van de diverse gemeentelijke afvalstoffenverordeningen en de vraag of hierin een uitvoeringsplicht is opgenomen. Net als Van Hulsteijn acht ik het verdedigbaar dat ook de verlening van een uitsluitend recht in overeenstemming met het VWEU moet zijn. ${ }^{\mathbf{1 2 0}}$ Ongeacht of sprake is van een concessie of van een vergunning waarbij een exclusief recht wordt verleend, zou in dit geval een transparante verdeelprocedure vereist zijn. 


\section{Afronding}

In dit artikel heb ik geprobeerd antwoord te geven op de vraag wat het Betfairarrest leert over de vraag op welke Nederlandse rechtsfiguren het 'Europese' transparantiebeginsel van toepassing zou kunnen zijn. Buiten twijfel is dat het transparantiebeginsel van toepassing is bij opdrachtverlening en concessieverlening zoals bedoeld in de Europese anbestedingsrichtlijnen. Uit het Betfair-arrest volgt dat ook voor de verlening van uitsluitende ('exclusieve') of bijzondere rechten in beginsel een transparante verdeelprocedure moet plaatsvinden, tenzij voldaan wordt aan de in dat arrest genoemde uitzondering. Dergelijke uitsluitende rechten kunnen bij vergunning worden verleend. Besluiten (met name vergunningen) die vergelijkbare gevolgen hebben als concessieovereenkomsten, omdat zij één partij (of enkele partijen) selecteren ten koste van anderen, moeten op grond van het Betfair-arrest, voldoen aan de Verdragsbeginselen, waaronder het transparantiebeginsel. Het toepassingsbereik van het aanbestedingsrechtelijke transparantiebeginsel is daarmee uitgebreid naar bepaalde soorten vergunningstelsels, namelijk naar stelsels waarbinnen schaarse vergunningen worden verstrekt. Hiervoor zijn enkele Nederlandse vergunning- en ontheffingsstelsels genoemd waarin sprake is van een dergelijke selectie.

Manunza maakt in haar preadvies voor de Vereniging van Bouwrecht onderscheid tussen 'aanbestedingsrecht stricto sensu' en 'aanbestedingsrecht in ruime zin'. Onder het aanbestedingsrecht in ruime zin valt volgens haar ook de verdeling van schaarse rechten bij vergunning. Zij ziet geen goede redenen om het mechanisme van de openbare aanbesteding te beperken tot de klassieke overheidsopdrachten. ${ }^{\mathbf{1 2 1}}$ De motieven die aan een aanbestedingsverplichting ten grondslag liggen ${ }^{\mathbf{1 2 2}}$, gelden immers even sterk bij de verstrekking van schaarse vergunningen en bepaalde subsidies. Volgens haar zou daarom overwogen kunnen worden om de reikwijdte van de Aanbestedingswet 2012 uit te breiden. ${ }^{123}$ Op basis van bovenstaande analyse kan ik mij vinden in deze visie op het 'aanbestedingsrecht in ruime zin'. Ook schaarse vergunningen moeten blijkens het Betfair-arrest transparant worden verleend. Deze verplichting om een transparante verdelingsprocedure te organiseren kan worden aangeduid als een 'aanbesteding light'. Daarmee bedoel ik dat bij de verlening van bepaalde schaarse besluiten, zoals vergunningen, geen volledige aanbesteding volgens de regels van de aanbestedingsrichtlijnen hoeft plaats te vinden, maar - gelet op het Betfair-arrest - wel een transparante verdelingsprocedure zal moeten plaatsvinden. De Awb bevat (nog) geen wettelijke regeling omtrent verlening van schaarse besluiten. Een dergelijke regeling zou zowel in de Awb als in de Aanbestedingswet 2012 kunnen worden opgenomen, waarin dan direct een verplichting tot een transparante verdeelprocedure zou kunnen worden opgenomen.

Om de reikwijdte van het transparantiebeginsel te kunnen bepalen is daarnaast van belang dat het Europees en nationaal recht aan rechtsfiguren met dezelfde benaming een andere uitleg geven. Dit heeft tot gevolg dat een Nederlandse vergunning met een uitvoeringsovereenkomst onder omstandigheden gekwalificeerd kan worden als concessieovereenkomst als bedoeld in de Europese aanbestedingsrichtlijnen. Voor een verdere ontwikkeling van het leerstuk van de schaarse publieke rechten is het daarom van belang dat de uitleg van diverse rechtsfiguren naar Nederlands en Europees recht wordt 
geharmoniseerd. Overwogen zou kunnen worden het begrip 'concessie' aan aanwijzing 125 van de Aanwijzingen voor de regelgeving toe te voegen. Hiermee wordt wetgevingsjuristen expliciet de mogelijkheid geboden om in plaats van een vergunning met uitvoeringsplicht, een concessiebesluit te introduceren.

Ten slotte zou de bestuursrechter bij de beslechting van geschillen over schaarse besluiten (meestal schaarse vergunnings- of ontheffingsstelsels) zich steeds de vraag moeten stellen of dit vergunnings- of ontheffingsstelsel materieel een concessiestelsel is dan wel een vergunning- of ontheffingsstelsel is dat dezelfde effecten heeft (omdat een exclusief of bijzonder recht wordt verleend). In beide gevallen zouden Verdragsbeginselen als het beginsel van gelijke behandeling en de transparantieverplichting door het bestuursorgaan in acht moeten worden genomen en zou de bestuursrechter daaraan dus dienen te toetsen. Concreet gevolg zou zijn dat meer vergunningstelsels voor de markt worden geopend.

\section{Noten}

1 HvJ EU 3 juni 2010, nr. C-203/o8, $A B$ 2011/17, m.nt. A. Buijze, JB 2010/171, m.nt. C.J. Wolswinkel en NJ 2010/491, m.nt. M.R. Mok.

2 Een selectie wordt in paragraaf 2 genoemd.

3 Een totalisator is een gelegenheid om op de uitslag van harddraverijen en paardenrennen te wedden.

4 Rechtbank Den Haag 8 december 2006, LJN AZ6335.

5 ABRvS 14 mei 2008, LJN BD1483.

6 Aldus r.o. 39-41 van het Betfair-arrest, waarbij het Hof tevens verwijst naar haar eerdere arresten Telaustria (HvJ EU 7 december 2000, nr. C-324/98), Eurawasser (HvJ EU 10 september 2009, nr. C-206/08), Wall (HvJ EU 13 april 2010, nr. C-91/o8), Coname (HvJ EU 21 juli 2005, nr. C-231/o3) en Coditel Brabant (HvJ EU 13 november 2008, nr. C-324/07).

7 R.o. 46.

8 R.o. 47.

9 R.o. 48-51.

10 R.o. 58-6o.

11 ABRvS 23 maart 2011, $A B$ 2011/230, m.nt. C.J. Wolswinkel, JB 2011/131 en NJB 2011/880.

12 H.M. Stergiou, 'Het Hof van Justitie: Engelbewaarder van het transparantiebeginsel. Een bespreking van het arrest Engelmann (zaak C64/o8) en tien jaar transparantierechtspraak van het Hof van Justitie', NTER 2011, p. 77 e.v. (hierna: Stergiou 2011). 
13 J. Mulder, 'A New Chapter in the European Court of Justice Gambling Saga: A Stacked Deck?', LIEI 2011, p. 243 e.v.

14 P.C. Adriaanse, T. Barkhuysen en S.C.G. van den Bogaert, 'Verdeling van schaarse kansspelvergunningen' in: F.J. van Ommeren, W. den Ouden en C.J. Wolswinkel (red.), Schaarse publieke rechten, Den Haag: Boom juridische uitgevers 2011, p. 159-174, alsmede van dezelfde auteurs 'Nederlandse kansspelregulering aan de Europese maat', NJB 2010, p. 1900-1907.

15 J.C.M. van der Beek, 'Het Nederlandse hoofdstuk in de Europese goksaga', NTER 2010, p. 305-317 (hierna: Van der Beek 2010).

16 HvJ EU 9 september 2010, nr. C-64/o8, NJ 2010/661. Zie eveneens Stergiou 2011.

17 HvJ EU 3 juni 2010, nr. C-203/o8, JB 2010, 171, m.nt. C.J. Wolswinkel.

18 Wie meer wil weten over het transparantiebeginsel en de jurisprudentie van het Hof hierover verwijs ik naar Stergiou 2011 alsmede naar A.W.G.J. Buijze, 'Waarom het transparantiebeginsel maar niet transparant wil worden', NTER 2011, afl. 7, p. 240-248.

19 Zie bijv. E.H. Pijnacker Hordijk, G.W. van der Bend en J.F. van Nouhuys, Aanbestedingsrecht. Handboek van het Europese en het Nederlandse Aanbestedingsrecht. Den Haag: Sdu Uitgevers bv, 2009, p. 100 (hierna: Pijnacker Hordijk 2009).

20 O.a. HvJ EU 10 maart 2011, nr. C-274/o9, Stadler/Passau en het arrest van 18 juli 2007 (nr. C382/o5) waarin het Hof oordeelt: “(...) dat de definitie van een overheidsopdracht voor dienstverlening tot het gebied van het gemeenschapsrecht behoort, zodat de kwalificatie van de litigieuze overeenkomsten naar Italiaans recht irrelevant is voor de beoordeling of deze overeenkomsten binnen de werkingssfeer van richtlijn 92/50 vallen (...).”

21 Zie bijv. ABRvS 23 november 2011, LJN BU5444.

22 Zie hierover ook de Conclusie van A-G Bot van 17 december 2009 bij het Betfair-arrest (nr. C-203/o8). Vgl. ook HvJ EU 19 juli 2012, nr. C-470/11, AB 2012/324, m.nt. A. Drahmann.

23 Artikel 1 van Richtlijn 2004/18/EG van het Europees Parlement en de Raad van 31 maart 2004 betreffende de coördinatie van de procedures voor het plaatsen van overheidsopdrachten voor werken, leveringen en diensten. Dit artikel is geïmplementeerd in het Besluit aanbestedingsregels voor overheidsopdrachten (Bao). Het Bao bevat een vergelijkbare begripsomschrijving.

24 De vraag kan worden gesteld wat de verschillen zijn tussen subsidie- en het opdrachtverlening, zeker als een subsidie wordt verleend na het volgen van een 'tenderprocedure'. De vervolgvraag is dan of en zo ja, wanneer het 
transparantiebeginsel bij subsidieverlening in acht moet worden genomen. In dit artikel laat ik de subsidieverlening verder buiten beschouwing en beperk ik mij tot de in het Betfair-arrest genoemde rechtsfiguren: de concessie en de vergunning. Wie meer wil weten over deze vragen verwijs ik naar: A. Drahmann, 'Is het strikte onderscheid tussen subsidie- en opdrachtverlening nog houdbaar?', Gst. 2011/115 en 'Kan het subsidierecht transparanter?', Gst. 2011/124.

25 Zie Stergiou 2011 voor een overzicht van deze jurisprudentie.

26 Artikel 1 van Richtlijn 2004/18/EG. Dit artikel is geïmplementeerd in het Bao. Het Bao bevat een vergelijkbare begripsomschrijving.

27 Richtlijn 2004/18/EG van het Europees Parlement en de Raad van 31 maart 2004 betreffende de coördinatie van de procedures voor het plaatsen van overheidsopdrachten voor werken, leveringen en diensten en Richtlijn 2004/17/EG van het Europees Parlement en de Raad van 31 maart 2004 houdende coördinatie van de procedures voor het plaatsen van opdrachten in de sectoren water- en energievoorziening, vervoer en postdiensten.

$28 \operatorname{COM}(2011) 897$ definitief. Zie over het nieuwe voorstel tevens B.J.H. BlaisseVerkooyen en D.C Orobio de Castro, 'Voorstellen van de Europese Commissie voor nieuwe aanbestedingsrichtlijnen (deel 2)', TBR 2012/69, G. 't Hart, 'Voorstel voor een concessierichtlijn: niet zonder water bij de wijn', TA 2012-03, p. 256 e.v. en K. Roffel en G.J.K. van den Hof, 'Het concessiebegrip in het Commissievoorstel betreffende de gunning van concessieopdrachten', $\mathrm{NtEr}$ 2012, p. 252-256.

29 Nijhof onderscheidt vijf materiële kenmerken voor een concessie in Europees perspectief. Het gaat om een overeenkomst (i), tussen de overheid als aanbestedende dienst (ii) en een aannemer (de concessiehouder) (iii) met het oog op de overdracht van de verantwoordelijkheid van een taak van algemeen belang ten behoeve van het publiek (iv) en de inkomsten van de concessiehouder bestaan uit het recht op exploitatie al dan niet in combinatie met een prijs (v). M.B. Nijhof, De concessie in Europeesrechtelijk perspectief, Deventer: Kluwer 2000, p. 21 en 27-49 (hierna: Nijhof 2000).

3o Artikel 2 lid 2 van het voorstel. De concessiehouder wordt geacht het wezenlijk operationeel risico op zich te nemen wanneer er geen garantie voorhanden is dat de gedane investeringen of de kosten die gemaakt zijn bij het exploiteren van de diensten die het voorwerp van de concessie vormen, kunnen worden terugverdiend. Dat economische risico kan bestaan uit het risico verbonden aan de vraag naar de verrichting van de dienst, of het risico verbonden aan de beschikbaarheid van de infrastructuur die door de concessiehouder wordt gebruikt voor de verrichting van diensten voor de gebruikers. Overweging (7) van het voorstel betreft ook de risico-overdracht. Het hoofdkenmerk van een concessie impliceert altijd de overdracht van een economisch risico met de mogelijkheid dat hij de gedane investeringen en de met diensten gepaard gaande kosten niet zal terugverdienen. Bepaalde regelingen die door een aanbestedende dienst volledig worden betaald 
kwalificeren als concessie wanneer het terugverdienen van de investeringen en de kosten die door de exploitant voor het verrichten van de diensten zijn gemaakt, afhangt van de werkelijke vraag naar of de beschikbaarheid van de dienst of het goed.

31 Interpretatieve mededeling van de Commissie over concessieovereenkomsten in het communautaire recht (2000/C 121/O2), PB C 121 van 29 april 2000.

32 Arrest HvJ EU 10 maart 2011, nr. C-274/o9, Stadler/Passau.

33 Vgl. HvJ EG 10 november 1998, nr. C-360/96 (Arnhem en Rheden/BFI Holding $B V$ ) waarin een dienstverleningsovereenkomst voor de inzameling van huishoudelijk afval was gesloten. Uit deze overeenkomst bleek dat de betaalde vergoeding uitsluitend bestond in een betaling en niet in het recht op exploitatie van de dienst.

34 In de Memorie van Toelichting wordt gesteld: "Indien de aanbestedende dienst de concessiehouder regelmatig vergoedingen geeft voor de uitvoering van het werk of de exploitatie ervan die voor een belangrijk deel het exploitatierisico wegnemen is er geen sprake meer van een concessieovereenkomst. Bij een dergelijke overeenkomst moet immers het exploitatierisico bij de concessiehouder liggen" (Kamerstukken II 2009/10, 32 440, nr. 3. p. 44).

35 Interpretatieve mededeling van de Commissie over concessieovereenkomsten in het communautaire recht (2000/C 121/o2), PB C 121 van 29 april 2000, p. 3.

36 Nijhof 2000, p. 9-12 en 125.

37 Opvallend is dat de titel van artikel 3 van Richtlijn 2004/18/EG luidt: "Toekenning van bijzondere of exclusieve rechten: nondiscriminatieclausule", maar dat in het artikel zelf wordt gerefereerd aan de verlening van "bijzondere of uitsluitende rechten". Het artikel luidt als volgt: "Toekenning van bijzondere of exclusieve rechten: nondiscriminatieclausule. Wanneer een aanbestedende dienst aan een lichaam dat zelf geen aanbestedende dienst is, bijzondere of uitsluitende rechten verleent om openbare diensten te verlenen, wordt in de akte waarbij deze rechten worden verleend, bepaald dat dit lichaam, bij de opdrachten voor leveringen die het in het kader van deze activiteit bij derden plaatst, het beginsel van niet-discriminatie op grond van de nationaliteit moet naleven."

38 Artikel 106 lid 1 VWEU luidt als volgt: "De lidstaten nemen of handhaven met betrekking tot de openbare bedrijven en de ondernemingen waaraan zij bijzondere of uitsluitende rechten verlenen, geen enkele maatregel welke in strijd is met de regels van de Verdragen, met name die bedoeld in de artikelen 18 en 101 tot en met 109."

39 Het begrip 'bijzondere of uitsluitende rechten' komt voor in overweging 25 en artikel 2 lid 3 van richtlijn 2004/17/EG. Overweging (25) luidt als volgt: "Het begrip bijzondere of uitsluitende rechten moet passend gedefinieerd worden. De definitie heeft tot gevolg dat het feit dat een dienst met het oog op de aanleg van 
netwerken of haven- of luchthavenfaciliteiten gebruik mag maken van een procedure voor de onteigening of het gebruik van eigendom, of faciliteiten mag installeren op, over of onder openbaar eigendom, als zodanig geen bijzonder of uitsluitend recht vormt in de zin van deze richtlijn. Ook het feit dat een dienst drinkwater, elektriciteit, gas of warmte levert aan een netwerk dat zelf geëxploiteerd wordt door een dienst waaraan door een bevoegde autoriteit van de betrokken lidstaat bijzondere of uitsluitende rechten zijn verleend, vormt als zodanig geen bijzonder of uitsluitend recht in de zin van deze richtlijn. Ook rechten die in enige vorm, ook via concessieovereenkomsten, door een lidstaat aan een beperkt aantal ondernemingen zijn toegekend op basis van objectieve, evenredige en niet-discriminerende criteria die eenieder die daaraan voldoet de mogelijkheid bieden van deze rechten gebruik te maken, kunnen niet worden aangemerkt als bijzondere of uitsluitende rechten." Artikel 2 lid 3 luidt als volgt: "Voor de toepassing van deze richtlijn zijn „bijzondere of uitsluitende rechten” rechten die voortvloeien uit een door een bevoegde autoriteit van de betrokken lidstaat verleende machtiging op grond van een wettelijke of bestuursrechtelijke bepaling die tot gevolg heeft dat de uitoefening van een van de in de artikelen 3 tot en met 6, omschreven activiteiten aan een of meer diensten voorbehouden blijft waardoor de mogelijkheden van andere diensten om dezelfde activiteit uit te oefenen wezenlijk nadelig worden beïnvloed.”

40 In de voorganger van Richtlijn 2004/17/EG (Richtlijn 93/38/EG houdende coördinatie van de procedures voor het plaatsen van opdrachten in de sectoren wateren energievoorziening, vervoer en telecommunicatie) was een andere definitie van bijzondere of uitsluitende rechten opgenomen. In het commissievoorstel voor de richtlijn (COM(2000) 276 definitief/2) wordt deze wijziging gemotiveerd met een verwijzing naar het arrest van het Hof van Justitie van 12 december 1996 (nr. C-302/94). Dit arrest heeft betrekking op het begrip "bijzondere of uitsluitende rechten" in het licht van de telecommunicatierichtlijnen. In Richtlijn 93/38/EEG heeft het begrip een andere betekenis. In de toelichting bij het richtlijnvoorstel wordt gesteld dat kwalijk is dat een zelfde begrip in Gemeenschapswetgeving betreffende de interne markt in ruime zin op twee verschillende wijzen wordt gedefinieerd. Daarom is voorgesteld de definitie van bijzondere of uitsluitende rechten in deze richtlijn te verduidelijken door rekening te houden met de definitie van het Hof van Justitie. Het gevolg hiervan is dat de aanbestedende diensten die uitsluitend onder het toepassingsgebied van de huidige richtlijn vallen omdat zij bijzondere of uitsluitende rechten genieten, niet langer onder de richtlijn zullen vallen.

41 Artikel 1, aanhef en onder bbb, van het Bao.

42 Artikel 1, aanhef en onder ccc, van het Bao.

43 Artikel 3 van Richtlijn 2004/18/EG bepaalt dat wanneer een aanbestedende dienst aan een lichaam dat zelf geen aanbestedende dienst is, bijzondere of uitsluitende rechten verleent om openbare diensten te verlenen, in de akte waarbij deze rechten worden verleend, wordt bepaald dat dit lichaam, bij de opdrachten voor leveringen die het in het kader van deze activiteit bij derden plaatst, het beginsel van niet-discriminatie op grond van de nationaliteit moet naleven. 
44 Interessant in dit verband is dat de begripsomschrijving in het Bao niet alleen is gebaseerd op de aanbestedingsrichtlijnen, maar ook op artikel 25a van de Mededingingswet, welk artikel een implementatie is van Richtlijn 2006/111/EG (transparantierichtlijn). De wetgever stelt in de memorie van toelichting bij de Aanbestedingswet 2012 (Kamerstukken II 2000/01, 27 870, nr. 3, p. 8-9.) dat de begripsomschrijving in beide richtlijnen in grote mate overeen komt en dat aannemelijk is dat, mede gelet op het feit dat deze begrippen afkomstig zijn uit artikel 106 VWEU daarmee hetzelfde wordt beoogd. Uit een oogpunt van eenheid van terminologie in Nederlandse wetgeving is in het wetsvoorstel aangesloten bij de omschrijving in de Mededingingswet. Hoofdstuk 4a van de Mededingingswet bevat voorschriften over financiële transparantie voor ondernemingen aan wie een uitsluitend of bijzonder recht is verleend.

45 Zie voor een overzicht van deze jurisprudentie: Stergiou 2011.

46 SEC (2011) 1169 definitief van 4 oktober 2011.

47 Dit artikel is geïmplementeerd in artikel 17 Bao. Dit artikel bepaalt dat het besluit niet van toepassing is 'op overheidsopdrachten voor diensten die door een aanbestedende dienst worden gegund aan een andere aanbestedende dienst of aan een samenwerkingsverband van aanbestedende diensten, op basis van een uitsluitend recht dat deze aanbestedende dienst geniet, mits dit uitsluitend recht met het Verdrag tot oprichting van de Europese Gemeenschap verenigbaar is.

Artikel 2.24, aanhef en onder a, van het voorstel voor een Aanbestedingswet 2012 bevat een vergelijkbare bepaling. In de memorie van toelichting wordt gesteld dat hiermee uitvoering wordt gegeven aan de artikelen 16 en 18 van Richtlijn 2004/18/EG.

In de Nederlandse versie van de richtlijn wordt in artikel 18 gesproken over een 'alleenrecht' in plaats van een 'exclusief recht'. In de Engelse versie van de richtlijn wordt wel consequent gesproken over 'exclusive rights'. Ook in het Bao (artikel 17 Bao) wordt consequent het begrip 'uitsluitende rechten' gebruikt.

48 Ook in de Interpretatieve Mededeling wordt gesteld dat geen Verdragsbepaling zich ertegen verzet dat lidstaten om niet-economische overwegingen van openbaar belang bepaalde diensten van openbaar belang aan de vrije mededinging onttrekken door een uitsluitend recht toe te kennen. De voorwaarden waaronder deze exclusieve rechten worden verleend, moeten echter wel voldoen aan de Verdragsregels.

49 Opvallend in dit verband is dat in het Bao de voorwaarde dat het recht moet worden toegekend op een andere wijze dan volgens objectieve, evenredige en niet-discriminerende criteria wel wordt genoemd in de omschrijving van een bijzonder recht, maar niet in de omschrijving van een uitsluitend recht. Dit heeft tot gevolg dat een door middel van bij voorbeeld een veiling verkregen monopolie een uitsluitend recht in de zin van het Bao blijft. In de aanbestedingsrichtlijnen worden de begrippen gezamenlijk genoemd.

50 In 2004 heeft de Europese Commissie een "Explanatory note" gepubliceerd 
die een nadere uitleg gaf over het begrip "bijzondere of uitsluitende rechten" in de zin van Richtlijn 2004/17/EC (Explanatory note - utilities directive: definition of exclusive or special rights (Document CC/2004/33)) Ook hier wordt al gesteld dat het nodig is om te bezien hoe het recht is verkregen. Als het recht is verkregen op basis van objectieve, proportionele en non-discriminatoire criteria dan is geen sprake van bijzondere of uitsluitende rechten als bedoeld in de richtlijn.

In artikel 4 lid 4 van het voorstel voor een concessierichtlijn wordt bepaald dat de richtlijn van toepassing kan zijn op entiteiten die activiteiten op basis van bijzondere of uitsluitende rechten uitoefenen. Er is géén sprake van een bijzonder of uitsluitend recht in de zin van het voorstel als een bijzonder of exclusief recht wordt verleend door middel van een procedure die is gebaseerd op objectieve criteria en waarvoor voor toereikende publiciteit is gezorgd. In de richtlijn wordt dus een bedrijf die over een uitsluitend recht beschikt zónder dat dit recht is verkregen door een transparante procedure zelf beschouwd als een aanbestedende entiteit als het zelf een concessie gunt. Een procedure die aan de eisen voldoet is een aanbesteding met voorafgaande inschrijving overeenkomstig de aanbestedings- of concessierichtlijnen of procedures uit hoofde van andere wetgevingshandelingen van de Unie met betrekking tot aardgas, elektriciteit, postdiensten, koolwaterstoffen en het openbaar personenvervoer.

51 Kamerstukken II 2009/10, 32 440, nr. 3. p. 43.

52 Daarnaast wordt gesteld dat het verschil tussen uitsluitende of bijzondere rechten en 'gewone' rechten is dat bij uitsluitende of bijzondere rechten het aantal ondernemingen dat over dat recht kan beschikken op voorhand is beperkt. Als voorbeelden van een 'gewoon' recht worden APK-garages en vestigingsvergunningen op grond van de Vestigingswet bedrijven 1954 genoemd (Kamerstukken II 2000/01, 27 870, nr. 3, p. 7-8).

$53 \mathrm{Vgl}$. B.J. Drijber en H. Stergiou, 'Public procurement law and internal market law', CMLR 2009, p. 805-846, i.h.b. p. 825-831 (hierna: Drijber \& Stergiou 2009).

54 J.M. Hebly, 'Bewust kiezen voor een nationaal aanbestedingsbeleid' in Hebly, Manunza \& Scheltema, Beschouwingen naar aanleiding van het wetsvoorstel Aanbestedingswet, Preadviezen voor de Vereniging voor Bouwrecht 2010, nr. 38, p.25-26 (hierna: Hebly 2010).

55 C. van Hulsteijn, 'Uitsluitend recht: uitsluitend onder exceptionele omstandigheden', TA 2012, p. 43-52 (hierna: Van Hulsteijn 2012).

56 Hebly 2010, p.25-26.

57 Vgl. Van der Beek 2010, p. 305-317, i.h.b. p. 315.

58 Richtlijn 2006/123/EG van het Europees Parlement en de Raad van 12 december 2006 betreffende diensten op de interne markt.

59 Zie uitgebreid over de Dienstenwet: C.J. Wolswinkel, 'Diensten tussen 
frequenties en kansspelen. Contouren van een Europees kader voor het verlenen van een beperkt aantal vergunningen', $S E W$ 2009/120 en C.J. Wolswinkel, 'The allocation of a Limited Number of Authorities, Some General Requirements from European Law', REALaw 2009-2, p. 61-104.

6o Artikel 4 van de Dienstenrichtlijn.

61 In overweging (57) wordt benadrukt dat de Dienstenrichtlijn betrekking heeft op vergunningstelsels die betrekking hebben op de toegang tot of de uitoefening van een dienstenactiviteit door marktdeelnemers en dus niet besluiten over de oprichting van een publieke of private entiteit voor het verrichten van een specifieke dienst of het aangaan van overeenkomsten met het oog op het verrichten van een specifieke dienst, waarop de regels inzake overheidsopdrachten van toepassing zijn.

62 Interpretatieve mededeling van de Commissie over concessieovereenkomsten in het communautaire recht (2000/C 121/02), PB C 121 van 29 april 2000, p. 4.

63 Artikel 12 van de Dienstenrichtlijn.

64 O.a. HvJ EU 22 december 2010, nr. C-338/o9 (Yellow Cab).

65 HvJ EU 19 juli 2012, nr. C-470/11, $A B$ 2012/324, m.nt. A. Drahmann.

66 Voor de vraag welke verplichtingen uit het transparantiebeginsel voortvloeien, verwijs ik naar A. Drahmann, 'Tijd voor een Nederlands transparantiebeginsel?' in: Europees offensief tegen nationale rechtsbeginselen? Over legaliteit, rechtszekerheid, vertrouwen en transparantie (Jonge VARreeks 8), Den Haag: Boom Juridische uitgevers 2010.

67 Deze aanwijzing is sinds 11 mei 2011 in de Ar opgenomen (Stcrt. 2011, 6602). Gesteld wordt dat als bij een vergunningstelsel in de zin van de Dienstenwet het aantal beschikbare vergunningen beperkt is, een selectieprocedure wordt ingesteld die alle waarborgen voor transparantie en onpartijdigheid biedt voor gegadigden, met inbegrip van een toereikende bekendmaking van de opening, uitvoering en afsluiting van de procedure. Een 'vergunningstelsel' is "elke procedure die voor een dienstverrichter de verplichting inhoudt om bij een bevoegde instantie stappen te ondernemen ter uitdrukkelijke of stilzwijgende toestemming voor de toegang tot of de uitoefening van een dienstenactiviteit”. In aanwijzing $125 \mathrm{Ar}$ is een verwijzing naar dit artikel opgenomen. In de toelichting wordt gesteld dat de Dienstenrichtlijn een andere definitie van de term vergunning hanteert dan aanwijzing 125 Ar. De verwijzing naar aanwijzing 131d Ar dient dan ook om de lezer op de afzonderlijke aanwijzing voor Dienstenrichtlijnvergunningen te wijzen.

$68 \operatorname{COM}(2011) 897$ definitief.

69 Dit blijkt ook uit overweging (6) van het voorstel voor een concessierichtlijn waarin wordt gesteld dat bepaalde staatshandelingen zoals machtigingen of 
vergunningen waarbij de staat of een overheid de voorwaarden voor de uitoefening van een economische activiteit vaststelt, niet als concessies kwalificeren. Hetzelfde geldt voor bepaalde overeenkomsten die tot voorwerp hebben het recht van een ondernemer om bepaalde publieke domeinen of rijkdommen te exploiteren, zoals pachtcontracten waarbij de staat enkel algemene voorwaarden voor het gebruik ervan vaststelt zonder bepaalde werken of diensten te verwerven.

70 Pijnacker Hordijk 2009, p. 100.

$7 \mathbf{1}$ In de nota van toelichting bij het Bao wordt over de elementen 'overeenkomst' en 'bezwarende titel' gesteld dat er geen sprake is van een overheidsopdracht wanneer middels een eenzijdige rechtshandeling (indirect) een opdracht wordt verleend, bijvoorbeeld het instellen van een dienst of het aanwijzen van een toezichthouder. Voor een overeenkomst onder bezwarende titel is niet noodzakelijk dat de aanbestedende dienst een prijs betaalt. Ook een andersoortige economische tegenprestatie, bijvoorbeeld een exploitatierecht, vormt een bezwarende titel (Stb. 2005, 408, p. 54).

72 In de memorie van toelichting bij de Aanbestedingswet 2012 wordt ook benadrukt dat het begrip overeenkomst betekent dat "de begripsomschrijvingen niet zien op eenzijdige rechtshandelingen als bijvoorbeeld het instellen van een dienst of een zelfstandig bestuursorgaan." (Kamerstukken II 2009/10, 32 440, nr. 3. p. 47.)

73 Aldus de memorie van toelichting bij de Mededingingswet. Zo staat tegenover het recht op distributie van elektriciteit in een bepaalde regio de plicht tot voorziening in onrendabele gedeelten van die regio (althans zolang de elektriciteitsvoorziening niet is geliberaliseerd). Een voorbeeld van een uitsluitend recht voor geheel Nederland is de exclusieve bevoegdheid tot het verrichten van bepaald postvervoer in Nederland op basis van de Postwet 2009. Een voorbeeld van regionale exclusieve rechten zijn nutsvoorzieningen, zoals een (gemeente)waterleidingbedrijf dat het uitsluitende recht heeft water te leveren binnen een bepaalde regio of het exclusieve recht om busvervoer in een bepaalde regio te verrichten (Kamerstukken II 2000/o1, 27 870, nr. 3, p. 7-8).

74 R.J.N. Schlössels en S.E. Zijlstra, De Haan/Drupsteen/Fernhout, Bestuursrecht in de sociale rechtsstaat, Deventer: Kluwer 2010, p. 811-812 en 836-837 (hierna: Schlössels \& Zijlstra 2010).

75 Stergiou 2011, p. 83.

76 Nijhof 2000, p. 27-29, 192-193, p. 231-236, p. 300-301 en 309.

77 D.L.M.T. Danker-Hagenaars, Op het spoor van de concessie. Een onderzoek naar het rechtskarakter van de concessie in Nederland en in Frankrijk, Den Haag: Boom juridische uitgevers 2000, p. 269 e.v. (hierna: Danker-Hagenaars 2000 - I). Zie eveneens D.L.M.T. Danker-Hagenaars, Het rechtskarakter van de concessie in Nederland, in 'De concessie, 'revival' van een oud instrument? Opstellen inzake de geschiedenis, het rechtskarakter en de toepassing van de 
concessie, in het bijzonder in de sfeer van Verkeer en Waterstaat', Ministerie van Verkeer Waterstaat 2000, p. 136-139. (hierna: Danker-Hagenaars 2000 - II).

78 S.E. Zijlstra, 'Burgerplichten en burgerlasten in het bestuursrecht', NTB 2009/1.

Zie ook HR 23 mei 2003, $A B$ 2004/157, m.nt. F.J. van Ommeren en Gst. 2003/137, m.nt. M.A. Heldeweg. In dit arrest was een wettelijke bepaling aan de orde die bepaalde dat een verleende goedkeuring van rechtswege verviel indien niet tijdig een afschrift van een bouwopdracht aan de minister werd toegezonden. De A-G stelt in zijn conclusie: "Hier is sprake van het verschijnsel dat in de rechtsliteratuur pleegt te worden aangeduid met de Duitse term Obliegenheit. Deze term ziet op situaties, waarin iemand een bepaalde gedraging moet verrichten op straffe van verval of beperking van aan hem toekomende rechten of bevoegdheden. In zulke gevallen is er geen sprake van een rechtsplicht (de betrokkene kan rechtens niet ertoe gedwongen worden), maar wel van een sanctie (als hij het niet doet, schaadt hij zijn eigen belang).” In het arrest was de vraag aan de orde op wie de plicht rustte om het afschrift aan de minister te sturen: de gemeente of de onderwijsstichting. De Hoge Raad gaat niet in op de term Obliegenheit en oordeelt (in essentie) op basis van de wetssystematiek dat sprake was van een rechtsplicht van de gemeente.

79 Interpretatieve mededeling van de Commissie over concessieovereenkomsten in het communautaire recht (2000/C 121/o2), PB C 121 van 29 april 2000, p. 4.

80 HvJ EG 12 juli 2001, nr. C-399/98, NJ 2002/11.

$\mathbf{8 1}$ Zo werd in deze procedure onder meer een verkavelingsovereenkomst tussen het gemeentebestuur en de eigenaar(s) van de te verkavelen terreinen gesloten. Het gemeentebestuur kon weliswaar zijn contractpartij niet kiezen, omdat deze persoon volgens de Italiaanse wet noodzakelijkerwijs de eigenaar van de te verkavelen terreinen was, maar deze omstandigheid sloot echter nog niet uit, dat de betrekking tussen het gemeentebestuur en de exploitant een contractueel karakter heeft, aangezien in de tussen hen gesloten verkavelingsovereenkomst werd bepaald, welke infrastructurele voorzieningen de exploitant telkens moest aanleggen, en wat de desbetreffende voorwaarden waren, waaronder mede de goedkeuring van de ontwerpen van deze voorzieningen door de gemeente. Bovendien beschikte de gemeente op grond van de door de exploitant in deze overeenkomst aangegane verbintenissen over een rechtstitel die hem de zekerheid gaf dat de aldus bepaalde voorzieningen beschikbaar waren met het oog hun openbare bestemming. Het theater moest (gedeeltelijk) worden verwezenlijkt 'overeenkomstig hun contractuele verplichtingen met betrekking tot het verkavelingsplan'.

82 Het Hof overweegt in r.o. 75: "Bovendien strookt deze uitlegging met het belangrijkste doel van de richtlijn, te weten (...) de openstelling van overheidsopdrachten voor de uitvoering van werken voor de mededinging. De openstelling voor de communautaire mededinging volgens de in de richtlijn vastgestelde procedures staat er immers garant voor, dat er geen gevaar voor onrechtmatige begunstigingen door de overheid bestaat. Dat de overheid haar contractpartij niet kan kiezen, kan dus op zich de niet-toepassing van de richtlijn 
niet rechtvaardigen, omdat een dergelijke eventualiteit ertoe zou leiden dat de uitvoering van een werk waarop deze richtlijn anders van toepassing zou zijn, van de communautaire mededinging wordt uitgesloten.”

83 HvJ EG 19 april 2007, nr. C-295/o5, NJ 2007/417, m.nt. M.R. Mok (Asemfo).

84 HvJ EG 18 december 2007, nr. C-220/o6, NJ 2008/281 (Correos).

85 HvJ EU 8 september 2010, nr. C-316/o7, NJ 2010/645 (Stoss).

86 HvJ EG 11 september 2003, nr. C-6/o1 (Anomar).

87 Interpretatieve mededeling van de Commissie over concessieovereenkomsten in het communautaire recht (2000/C 121/O2), $P B$ C 121 van 29 april 2000, p. 4 en 10. Zie ook Drijber \& Stergiou 2009, p. 805-846.

88 Zie ook Nijhof 2000, p. 27-29, 192-193, p. 231-236, p. 300-301 en 309. Nijhof stelt dat het niet relevant is of een overeenkomst een publiek of privaat karakter heeft.

89 Vgl. Van Wijk/Konijnenbelt \& Van Male, Hoofdstukken van bestuursrecht, 15e dr., Amsterdam 2011, p. 193.

90 De Beschikking BankGiro Loterij 2008 (art. 7), de Beschikking instantloterij 2011-2015 (art. 6), de Beschikking Nationale Postcode Loterij 2008 (art. 7), de Beschikking SNL Loterij 2009 (art. 7), de Beschikking Sporttotalisator 2010 (art. 6-8) en de Beschikking Vriendenloterij 2011 (art. 7)

91 Aanwijzing 125 Ar.

92 Schlössels \& Zijlstra (Schlössels \& Zijlstra 2010, p. 811-812) hanteren een eigen begripsomschrijving die soms afwijkt van de definities in de Ar. Volgens Schlössels \& Zijlstra is de vergunning een uitzondering op een verbod terzake van handelingen die de overheid op zichzelf niet onwenselijk acht, maar die zij alleen op een bepaalde wijze wil doen plaatsvinden.

93 Aanwijzing 125 Ar. Volgens Schlössels \& Zijlstra (Schlössels \& Zijlstra 2010, p. 811-812) is de vrijstelling het spiegelbeeld van de vergunning, namelijk de uitzondering op een algemeen gebod (bijv. de vrijstelling van de dienstplicht zoals die vroeger bestond). De bekendste 'vrijstelling' is wellicht de inmiddels vervallen vrijstelling van het bestemmingsplan op grond van artikel 19 WRO. Deze 'vrijstelling' voldoet dus echter niet aan de omschrijving van Schlössels \& Zijlstra.

94 Aanwijzing 125 Ar. Volgens Schlössels \& Zijlstra (Schlössels \& Zijlstra 2010, p. 811-812) is de ontheffing een uitzondering op een verbod of een gebod, en betreft het handelen respectievelijk nalaten waar de overheid in beginsel wél afwijzend tegenover staat, en die zij alleen in uitzonderlijke gevallen wil toestaan. 
95 Aanwijzing 125 Ar.

96 Schlössels \& Zijlstra 2010, p. 811-812 en 836-837.

97 Volgens Danker-Hagenaars kunnen vijf toetsingscriteria voor een concessie worden onderscheiden: (1) de concessie wordt verleend door de overheid; (2) de concessie wordt verleend ter behartiging van een algemeen belang; (3) de concessie is bestemd tot gebruik door het publiek; (4) de concessionaris wordt althans gedeeltelijk betaald door de gebruikers/afnemers van de concessieactiviteit; en (5) de concessie roept een rechtsverhouding in het leven tussen de concessiegever en de concessiehouder. Danker-Hagenaars 2000 - I, p. 64 e.v. en p. 269 e.v. en . 269 e.v. en Danker-Hagenaars 2000 - II, p. 136-139.

98 Danker-Hagenaars 200o, p. 13 e.v.

99 Nijhof 2000, p. 236-238.

100 Schlössels \& Zijlstra 2010, p. 839.

101 Danker-Hagenaars 2000, p. 13 e.v.

102 Schlössels \& Zijlstra 2010, p. 840. In 1996 pleitte Nijholt er zelfs voor om aanbestedingsovereenkomsten te kwalificeren als publiekrechtelijke overeenkomsten (H. Nijholt, Op weg naar een bestuursrechtelijke normering van het gemeentelijk aanbestedingsbeleid in de bouw, Deventer: Kluwer, 1996, p. 151-157).

103 Hiervoor is al gesteld dat volgens Schlössels \& Zijlstra (Schlössels \& Zijlstra 2010, p. 811-812) de ontheffing een uitzondering is op een verbod of een gebod. Het betreft handelen respectievelijk nalaten waar de overheid in beginsel wél afwijzend tegenover staat, en die zij alleen in uitzonderlijke gevallen wil toestaan.

104 De Beschikking BankGiro Loterij 2008 (art. 7), de Beschikking instantloterij 2011-2015 (art. 6), de Beschikking Nationale Postcode Loterij 2008 (art. 7), de Beschikking SNL Loterij 2009 (art. 7), de Beschikking Sporttotalisator 2010 (art. 6-8) en de Beschikking Vriendenloterij 2011 (art. 7).

105 Zie tevens de Beleidsvisie Kansspelen (Kamerstukken II 2010/11, 24 557, nr. 124).

106 Besluit van 22 december 2011, nr. WJZ/11168400, houdende bekendmaking van het via de procedure van veiling verdelen van vergunningen voor frequentieruimte in de 800, 900 en 1800 MHz-band, Stcrt. 2012, nr. 395 en de Regeling aanvraag- en veilingprocedure vergunningen 800, 900 en 1800 MHz, Stcrt. 2012, 392.

107 Regeling aanvraag- en veilingprocedure vergunningen 800, 900 en 1800 MHz, Stcrt. 2012, 392, p. 47-48. Zie over de verdeling van frequenties tevens: N.A.N.M. van Eijk en A.W. Hins, 'Verdeling van radiofrequenties' in: F.J. van 
Ommeren, W. den Ouden \& C.J. Wolswinkel (red.), Schaarse publieke rechten, Den Haag: Boom juridische uitgevers 2011, p. 45-70.

108 De concessie voor het beheer van de hoofdweginfrastructuur (die is verleend aan ProRail) wordt verleend op grond van de Spoorwegwet.

109 Art. 1, aanhef en onder l. Wp2ooo.

110 Op grond van artikel 1 van de Regeling veiling benzinestations langs rijkswegen is de 'directeur Domeinen' de directeur van de regionale directie Domeinen West te Leiden. 'Domeinen' is de dienst Domeinen van het Ministerie van Financiën.

111 Kamerstukken II 2004/o5, 29 951, nr. 3, p. 1-2.

112 Deze verdeelprocedure is als volgt: 'Indien er vergunningen worden aangevraagd voor meer energielaadpunten dan er ruimte is op een verzorgingsplaats worden de aangevraagde energielaadpunten naar evenredigheid verdeeld onder de aanvragers, maar zodanig dat iedere aanvrager minimaal één energielaadpunt wordt vergund. Indien ook dan nog onvoldoende plaats is, wordt er onder de aanvragers geloot.' (Stcrt. 2011, 23149)

113 Het hier gekozen ontheffingstelsel past binnen de omschrijving van Schlössels \& Zijlstra (Schlössels \& Zijlstra 2010, p. 811-812) dat de ontheffing handelen respectievelijk nalaten betreft waar de overheid in beginsel afwijzend tegenover staat, en die zij alleen in uitzonderlijke gevallen wil toestaan, omdat de zondagsrust wordt verstoord door de ontheffingverlening.

114 O.a. CBb 8 januari 2010, $A B$ 2010/73, m.nt. I. Sewandono, Vz CBb 7 juli 2011, $A B$ 2011/179 en CBb 7 december 2011, $A B$ 2012/55, beide m.nt. C.J. Wolswinkel.

115 Over afvalinzameling bestaat al jurisprudentie, o.a. Hof Arnhem 25 juni 1996, BR 1996, p. 753, ABRvS 28 oktober 1996, BR 1997, p. 269 en $A B$ 1997/17, m.nt. F.C.M.A. Michiels.

116 HR 18 november 2011, LJN BU4900 (AVR/Westland).

$\mathbf{1 1} 7$ Er wordt volgens de Hoge Raad voldaan aan de zogenaamde 'Teckaldoctrine', nu (1) HVC een overheidsbedrijf is, (2) HVC de verwerking van huishoudelijk afval slechts verricht ten behoeve van de in haar deelnemende gemeenten, (3) er geen aanwijzingen zijn dat eventuele andere activiteiten van HVC ten opzichte hiervan veel meer dan marginaal zijn en (4) voldaan is aan artikel 17 Bao.

118 Zie tevens F.J. van Ommeren en J. Vermont, 'Uit- en aanbesteden in het publiek- en privaatrecht? De uitbesteding van het recht om huishoudelijk afval in te zamelen', Gst. 2007/7. Zie tevens rechtbank Den Bosch 27 april 2012 (LJN BW6321), maar anders: Rechtbank Leeuwarden 27 januari 2010 (LJN BLo852) en rechtbank Den Haag 29 februari 2012 (LJN BW5722). 
119 Men zou ook nog van mening kunnen verschillen over de vraag of sprake zou kunnen zijn van een concessie of opdracht. Het Hof van Justitie heeft eerder over een dienstverleningsovereenkomst voor de inzameling van huishoudelijk afval geoordeeld dat sprake was van een opdracht, omdat uit deze overeenkomst bleek dat de betaalde vergoeding uitsluitend bestond in een betaling en niet in het recht op exploitatie van de dienst (HvJ EG 10 november 1998, nr. C-36o/96, Arnhem en Rheden/BFI Holding BV).

120 Van Hulsteijn 2012, p. 46. Manunza vroeg zich in 2001 al af of dit soort publiekrechtelijke overeenkomsten niet binnen de reikwijdte van de richtlijn zouden (moeten) vallen (E.M. Manunza, EG-aanbestedingsrechtelijke problemen bij privatiseringen en bij de bestrijding van corruptie en georganiseerde criminaliteit, Deventer: Kluwer, 2001, p. 192-193).

121 E.R. Manunza, 'Naar een consistente en doelmatige regeling van de markt voor overheidsopdrachten' in Hebly, Manunza \& Scheltema 2010, p.59.

122 Manunza concludeert dat met een openbare aanbesteding zowel de rechtmatigheid (vanwege het neveneffect van corruptiebestrijding en de bevordering van gelijke kansen van geïnteresseerde burgers) als de doelmatigheid (vanwege de effectieve besteding van belastinggelden) van overheidsbestedingen wordt gediend (Manunza 2010, p.85-86).

123 Manunza 2010, p. 109-111. 